Article

\title{
Proportional Variation of Potential Groundwater Recharge as a Result of Climate Change and Land-Use: A Study Case in Mexico
}

\author{
Jesús Guerrero-Morales ${ }^{1}$, Carlos R. Fonseca ${ }^{2, *} \mathbb{*}$, Miguel A. Goméz-Albores ${ }^{2}$ (D), \\ María Laura Sampedro-Rosas ${ }^{1}$ (D) and Sonia Emilia Silva-Gómez ${ }^{3}$ \\ 1 Centro de Ciencias de Desarrollo Regional, Universidad Autónoma de Guerrero, Acapulco 39640, Mexico; \\ 17250417@uagro.mx (J.G.-M.); 05156@uagro.mx (M.L.S.-R.) \\ 2 Instituto Interamericano de Tecnología y Ciencias del Agua, Universidad Autónoma del Estado de México, \\ Toluca 50100, Mexico; magomeza@uaemex.mx \\ 3 Posgrado en Ciencias Ambientales, Instituto de Ciencias, Benemérita Universidad Autónoma de Puebla, \\ Puebla 72570, Mexico; sonia.silva@correo.buap.mx \\ * Correspondence: crfonsecao@uaemex.mx; Tel.: +52-(722)-965-550
}

Received: 12 August 2020; Accepted: 30 September 2020; Published: 1 October 2020

\begin{abstract}
This work proposes a methodology whereby the selection of hydrologic and land-use cover change (LUCC) models allows an assessment of the proportional variation in potential groundwater recharge (PGR) due to both land-use cover change (LUCC) and some climate change scenarios for 2050. The simulation of PGR was made through a distributed model, based on empirical methods and the forecasting of LUCC stemming from a supervised classification with remote sensing techniques, both inside a Geographic Information System. Once the supervised classification was made, a Markov-based model was developed to predict LUCC to 2050. The method was applied in Acapulco, an important tourism center for Mexico. From 1986 to 2017, the urban area increased 5\%, and by 2050 was predicted to cover $16 \%$. In this period, a loss of 7 million $\mathrm{m}^{3}$ of PGR was assumed to be caused by the estimated LUCC. From 2017 to 2050, this loss is expected to increase between 73 and 273 million $\mathrm{m}^{3}$ depending on the considered climate change scenario, which is the equivalent amount necessary for satisfying the water needs of 6 million inhabitants. Therefore, modeling the variation in groundwater recharge can be an important tool for identifying water vulnerability, through both climate and land-use change.
\end{abstract}

Keywords: land-use change; potential groundwater recharge; climate change

\section{Introduction}

Land-use cover change (LUCC), especially the transformation of natural vegetation to agricultural and urban uses, can directly modify the hydrological cycle, resulting in increased flooding and decreased groundwater recharge, among other effects [1-4]. In agricultural areas, the topsoil compaction leads to a loss of the water retention and infiltration capacity of the subsurface. In urban areas, the introduction of relative impermeable materials or surfaces prevents groundwater recharge $[5,6]$.

Precipitation, lateral flow from adjacent unconfined aquifers, irrigation practices and pipeline leakage are the main sources of groundwater recharge [7-9]. The vertical water that drains from the surface to the root zone (unsaturated zone) is called infiltration [10], and the subsequent displacement of water by capillarity and gravity to the groundwater (saturated zone) is called percolation [9]. Hence, for this study, the potential groundwater recharge (PGR) is related to the vertical flow from precipitation that has the potential to percolate to the aquifer $[8,9]$, and the main factors that allow this PGR, in addition to precipitation, are temperature, land use, soil permeability and terrain slope $[11,12]$. 
Among these factors, land-use and climate change imply both dynamics and heterogeneity features [12-15]. That is why Yalew et al. [16] suggest considering land-use changes over time to generate more accurate hydrological scenarios. However, introducing LUCC into hydrological scenarios implies both a classified image of land-use and validated LUCC forecasting. To generate supervised classification images of land-use, some authors, such as Aburas et al. [17], have shown satisfactory results with the maximum likelihood classification algorithm, and to project the LUCC over time, models based on Artificial Neural Network and Markov Chains could better depict its complex non-linear and long-term process [18-20].

On the other hand, there is a wide variety of hydrological models classified by their parameters as functions of space and time, i.e., semi-distributed models and distributed models. For several cases, satellite imagery of remote sensors can be used to generate the input information required by those models [21,22]. For example, Yalew et al. [16], Li et al. [23] and Zhang et al. [24] examined surface run-off considering LUCC estimated from AVHRR, MODIS and MERIS products. Their results showed the significant influence of LUCC as the proportional variation of run-off reached a value of up to $35-65 \%$. Nevertheless, despite the fact that almost half of the domestic water needs [25] and more than a third of irrigation consumption [26] are met by groundwater resources, the research has lacked corresponding research on surface water resources in terms of the effect of both climate change [27] and LUCC.

A global-scale study [28] shows changes from approximately $-30 \%$ to $100 \%$ in average groundwater recharge, and by the 2050s about 110 million people may be affected by its decrease depending on the climate model [28]. Other studies [25-35] have downscaled the effect of climate change on groundwater recharge, but all of them were carried out in northern latitudes (USA, Canada, UK, Belgium) or Australia.

In some other studies [1,6,12-14], the effect on groundwater recharge of LUCC was estimated, with no regard for future climate change. Two approaches to the combined effect could be seen in the work of Bronstert [36] and Marhaento et al. [15], highlighting their orientation towards the surface water resources.

In this context, the population percentage living in cities is $54 \%$ worldwide [37,38]; however, several types of human settlements, such as tourism areas, are more rapidly expanding around the world [37,39-41]. In the study case of Acapulco de Juárez, México, LUCC has been constantly growing since the 2050's because of the urban development projects to satisfy the needs of the tourism sector $[37,42]$. In addition to the LUCC, the hydrological balance in low-latitude regions could be more affected, due to the effect of climate change on evaporation and rainfall $[1,15,43]$.

The importance of the present work relies on the estimation of the effect of LUCC and climate change, separately and combined, on groundwater resources in a tropical region. For this, a brief discussion is made on the selection of a hydrologic model based on its spatial approach and the future projection of the involved variables.

\section{Study Area}

Acapulco de Juárez is located in the state of Guerrero, México. It has a population of 810,669 inhabitants and has experienced annual growth of 11,000 inhabitants from 1980 to 2015 [44]. According to the World Health Organization [45], each inhabitant requires $0.12 \mathrm{~m}^{3}$ of drinking water per day to satisfy their basic needs. However, the water demand may be even higher considering that Acapulco is an important tourist destination that receives approximately 500,000 tourists per year [46]. Tourism is the dominant industry, whilst agricultural, mining and industrial activities are present to a lesser extent [47]. Several terrestrial ecosystems are present, including pine and/or oak forest, evergreen rainforest, tropical dry forest and grasslands. Mangroves and coastal dunes are also encountered along a $62 \mathrm{~km}$ stretch of coastline [48].

The climate of the region is mainly humid and sub-humid tropical. The average annual temperature ranges from 20 to $27.7^{\circ} \mathrm{C}$, and the annual rainfall ranges from 1120 to $1663 \mathrm{~mm}$ [49]. The topography of the region is rugged, ranging from 0 to 2079 m.a.s.l. [50]. The main water bodies include the Sabana 
and Papagayo Rivers, Tres Palos Lagoon, and the El Veladero Protected Natural Area, where human settlements are prohibited (Figure 1) [51]. Accordingly, this area has not experienced LUCC, and was considered as restricted by LUCC in the analysis. This region covers two aquifers, Acapulco Bay and La Sabana. Both present similar characteristics, as follows: unconfined aquifers, hydraulic conductivity from 0.12 to $9.12 \times 10^{-3} \mathrm{~m} / \mathrm{s}$, and transmissivity between 1.5 and $120 \times 10^{-3} \mathrm{~m}^{2} / \mathrm{s}$. About lithology, the aquifers show a predominance of unconsolidated sediments and metamorphic rocks, and according to official sources, the information on depth to the water table is scarce. Some data indicate values from just a few centimeters in the bay to $9 \mathrm{~m}$ at the urban zone $[52,53]$.

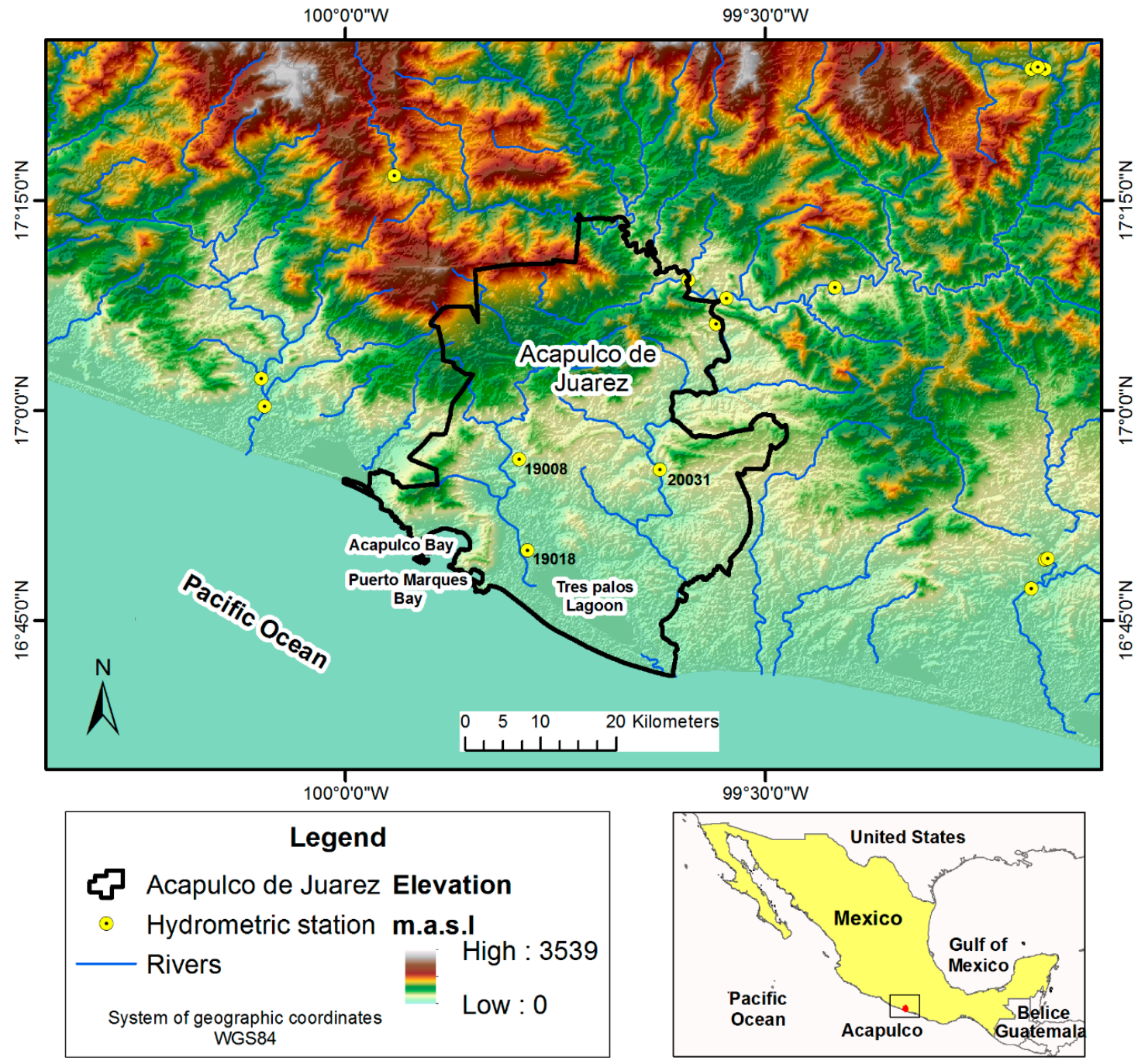

Figure 1. Study case location, water bodies and elevation [40].

With respect to tourism, the main infrastructure is concentrated around the Bays of Acapulco and Puerto Marqués Bay. In 1950, 246 ha were identified as belonging to the tourism sector by Carrascal and Pérez [54]. Since then, this area had increased to 450 ha for 1989. From 1987 to 1993, the most significant tourism development of Acapulco was built: The Zona Diamante. This urban project involved a land-use change of 270 ha, extending from Puerto Marqués Bay toward the western portion of the municipality between the Pacific Ocean and Tres Palos Lagoon [54]. Several other tourism and residential buildings have been constructed in low-lying areas near the coast. The most susceptible areas to flooding are located in the southern portion of the municipality and to the southwest of Tres Palos Lagoon. Notably, two large hotel complexes with an extension of approximately 133.7 ha along 
Puerto Marqués Bay are located at no more than 20 m.a.s.l. and, therefore, are highly susceptible to flooding $[44,54]$.

Concerning some explanatory variables of LUCC (Table 1), roadways are triggers of urban and agricultural growth $[55,56]$ because they enable higher access and the transport of merchandise. Existing human settlements tend to expand given their proximity to existing public services, among other factors [57]. For this reason, buffers based on the distance to urban centers in 2003 and roadways were created $[48,58]$. Given the rugged topography of the area, it is also important to consider the slope and elevation as explanatory variables. Given that roadways reinforce urban LUCC because they provide access to services and businesses, the national roadway networks of 2014-2017 were also considered as an explanatory variable for LUCC.

Table 1. Explanatory variables, incentives and constraints.

\begin{tabular}{ccc}
\hline Explanatory Variables & Source & Type \\
\hline Distance to urban centers & {$[59]$} & Infrastructure \\
Distance to roads & {$[60]$} & Infrastructure \\
Slopes & {$[50]$} & Topography \\
Temperature & {$[49]$} & Climate \\
Precipitation & {$[49]$} & Climate \\
Digital elevation model & {$[50]$} & Topography \\
\hline Incentives and constraints & Source & Type \\
\hline El Veladero & {$[51]$} & Politics \\
National roads network 2014, 2015, 2016, 2017 & {$[61]$} & Infrastructure \\
\hline
\end{tabular}

\section{Materials and Methods}

This section (Figure 2) presents the supervised classification methodology for determining land-uses from 1986, 2003 and 2017, as well as the determination of LUCC in 2017 using a predictive model, and its validation of current land-uses. The model was then used to forecast land-uses by 2050. Finally, the variation in potential groundwater recharge during the study period was estimated through a distributed model.

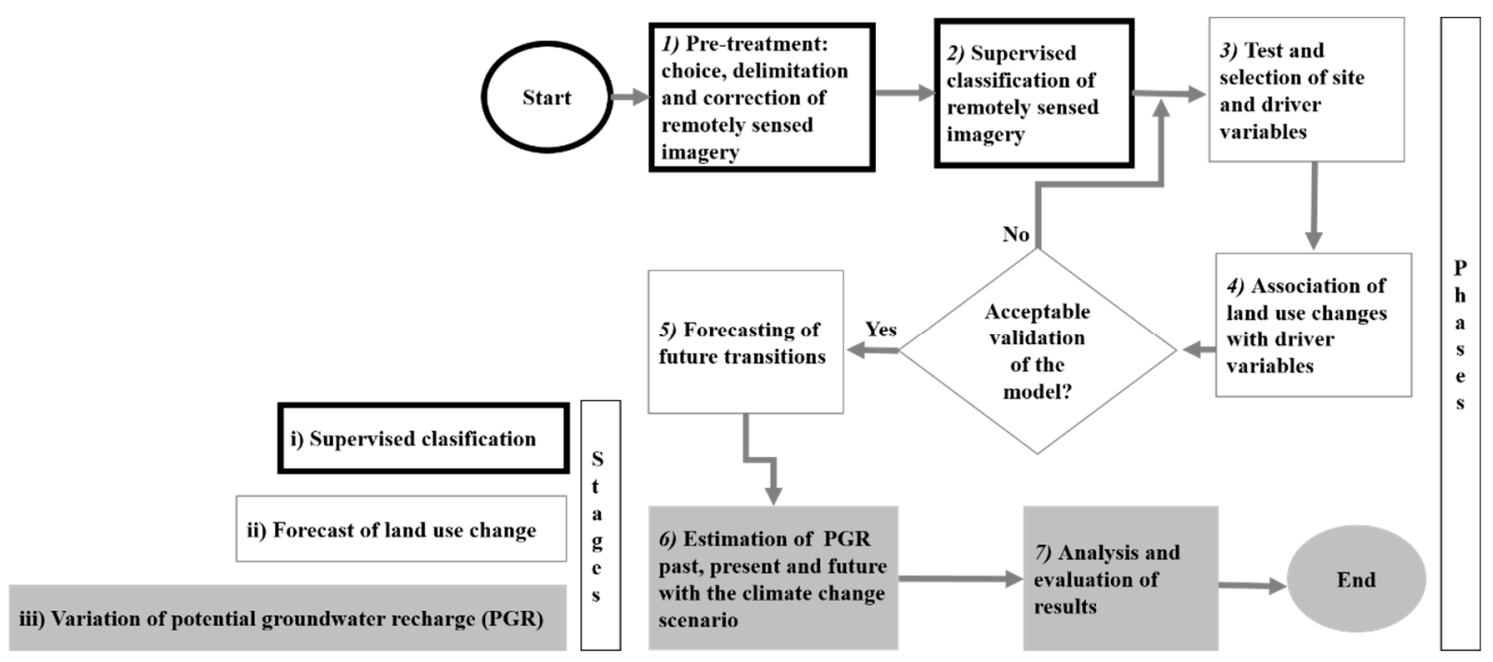

Figure 2. Methodological scheme for estimating potential groundwater recharge.

\subsection{Supervised Image Classification}

Table 2 shows the characteristics of the satellite images of Landsat 5 TM, 7 ETM + and 8 OLI (Path/Row 26/48) used in this study for April 1986, 2003 and 2017 respectively, as well as those downloaded from the website of the United States Geological Survey [62], which provides free-access 
images with adequate geometric correction for multi-temporal analyses [2,61,63]. The year 1986 was selected as it is the year before the construction of the largest urban increases registered in the study area (Zona Diamante), mainly driven by the high tourist demand. Besides, a period of 31 years is suggested as the minimum time required to validate a predictive model of LUCC [64,65].

Table 2. Acquired Landsat images [62].

\begin{tabular}{cccccc}
\hline Satellite & Sensor & Acquisition Date & Resolution & Composition of Bands & Path, Row \\
\hline Landsat 5 & TM & 24 April 1986 & $30 \mathrm{~m}$ & 234,345 & 026,048 \\
Landsat 7 & ETM & 15 April 2003 & $30 \mathrm{~m}$ & 234,345 & 026,048 \\
Landsat 8 & OLI & 13 April 2017 & $30 \mathrm{~m}$ & 345,456 & 026,048 \\
\hline
\end{tabular}

The spectral bands were segmented for those three years using a watershed-based algorithm in the TerrSet (Version 18.31) software [60,66], and the training sites were chosen in the segmented images. For the first two years, these were selected from well-known sites identified on orthophotos (Table 3). For 2017, they were selected through a field review and, by consulting Google Earth [67,68] following a similar spectral response pattern, visually homogenous and evenly distributed across the images according to Mondal et al. [68].

Table 3. Support cartographic material for training sites choosing.

\begin{tabular}{cccc}
\hline Cartographic Material & Scale & Acquisition Date & Source \\
\hline Orthophotos & $1: 20,000$ & 1995 & {$[69]$} \\
Orthophotos & $1: 10,000$ & 2007 & {$[69]$} \\
Google Earth® & - & 2017 & {$[70]$} \\
\hline
\end{tabular}

The training sites were evaluated by estimating the separability of the spectral signatures via the transformed divergence, which is a statistical method that compares the mean and co-variance of pairs of spectral signatures to evaluate the accumulated difference between the training sites of the selected land-uses. Accordingly, it was possible to perform the supervised classification using the maximum likelihood algorithm [71,72].

\subsection{Land-Use Change Forecasting}

The land-use change forecasting consisted of the selection and evaluation of the explanatory variables of LUCC, such as the urban infrastructure, topography and climate. Liang et al. [56] mentioned that the distance to roadways and human settlements is a crucial determinant of LUCC [61]; also, orographic characteristics, such as slope and elevation, define the speed of agricultural and urban expansion [73]. To further evaluate the association between the LUCC and explanatory variables, the Cramer's V test was used, considering values between 0.15 and 0.4 as indicators of an acceptable relationship between the land-use change and the explanatory variable $[58,66,73]$.

A neuronal network algorithm was applied to calculate the transition potentials. This algorithm is one of the most applied because it can solve complex variables and provide highly precise results [74,75]. The forecasting process was performed using Markov chains [61,74,76]. The land-uses in 2017 were forecasted and validated using the Kappa statistic [74,77] and the ROC curve, which compared the coincidence between the forecasted and actual land-uses [77]. Once we had validated this model, an image of land-use in 2050 was constructed.

\subsection{Estimation of PGR}

Estimating PGR through a hydrological balance leads to a series of decisions, which must be made on the following: the selection of methods for determining evapotranspiration, runoff, etc.; hydrological models providing information with adequate space and time formats; and even the complexity of 
the model. As this study focuses on LUCC, it requires a model able to provide information with a territorial approach that is as simple as possible, to keep the PGR projection in the future lying just within the forecast of temperature, rainfall and LUCC.

According to its parameters as a function of space, a model could be semi-distributed or distributed. For instance, it is possible to find semi-distributed models such as HBV-model [78], the Variable Infiltration Capacity (VIC) model, which is recommended for humid and agricultural areas [79,80], or the soil and water assessment tool (SWAT), which focuses on agricultural areas [80]. There is also TOPMODEL, which is used for moderate topography [80,81].

These models are often calibrated and validated in a given time, and when they are applied throughout long periods, the land-use is assumed to be time-invariant. In this case, it is implausible to assume that the model parameters are still suitable when large extensions of land-use have changed [23]. Therefore, in the present study a distributed model is preferred, where parameters, inputs and outputs can vary spatially.

Among the distributed models and according to Devi et al. [80], the conceptual ones are simple and can be easily implemented in computer code, unlike the psychically-based ones that are complex, require human expertise and computational capability, and suffer from scale-related problems.

The conceptual distributed models are usually composed of a production function (or generation routine) and a transfer function (or concentration routine). This approach allows one in the first place to estimate vertical flows (e.g., PGR) in each cell of the distributed model grid, independent from characteristics changes (such as LUC) on the other cells. Secondly, the transfer function estimates the runoff concentration as an output that could be validated with field measures.

Some models work inside a Geographic Information System (GIS) environment; for example, InVEST Water Yield Model is a model that estimates the water yield as a percentage of precipitation based on the Budyko curve [82]. Nevertheless, no distinction is made between a sub-surface and surface flow [83]. Given this lack of distinction, in this work, the production function for PGR estimation (step 6) and its variation over time (step 7) is carried out by another GIS environment module [84]. As well as other models, this tool estimates PGR by abstracting from the precipitation, the potential evapotranspiration (PET) and the surface runoff monthly. Precipitation imagery every month from 1980 to 2018 was obtained from the databases of Thornton et al. [85].

As regards PET, the Thornthwaite method [86] was considered adequate due to its impact on runoff assessment under climate change and its feasibility in the study zone. Variation in rainfall and temperature as a result of climate change modifies evapotranspiration [87] and the overall hydrological cycle. Under climate change, Yates and Strzepeck [88] found this method to be better-ranked compared to Hargreaves', and just below the Priestley-Taylor method in terms of the standard error. The latter one, as well as the Penman method, is a physically-based model, and therefore data-intensive and data-sensitive. Furthermore, the temperature-based methods may be sufficient for large scales, if it is assumed that other climate variables covary with temperature [89]. Pan's et al. [90] calculations demonstrate the global increase tendency of evapotranspiration on the order of $60 \%$ to $80 \%$ in some regions up to 2090. It is also noticed that different climatological regions show different trends in PET estimations depending on the method [88]. For instance, Thornthwaite tends to underestimate PET in sub-tropics, and this is most likely because the method was originally calibrated in humid environments [89]. This allows for inferring that the method could be feasible in regions with enough relative humidity like the present study zone ( $>75 \%)$. In this case, Van der Schrier et al. [91] show a difference from -0.1 to $0.1 \mathrm{~m} /$ year of PET between Thornthwaite and Penman methods.

On the other hand, the surface runoff is depicted by a coefficient Keij as the ratio between the runoff and rain [92,93], which involves slope, altitude, soil type and land-use.

The soil type was associated with its permeability based on the soil classification of INEGI [94]. The Regosol soil type was linked with high permeability, while the Solonch and Phaeozem soil types were associated with low and medium permeability, respectively. The Ke ranges from 0.8 to 0.35 for low, 0.7 to 0.25 for medium and 0.5 to 0.05 for high permeability depending on slope and land-use $[95,96]$. 
A digital elevation model (DEM) with $13.5 \mathrm{~m}$ of spatial resolution [50] was used to estimate the slope of the terrain. Later, the slope was categorized into high ( $>50 \%)$, moderate ( $5 \%$ to $20 \%$ ) or low $(0 \%$ to $1 \%[93,97,98])$. About the land-use, it was classified according to categories usually found in the literature $[8,11,82,99]$ and following the classification for LUCC: (a) urban zone (populated areas); (b) croplands; (c) forest areas; and (d) water bodies.

The surface runoff was validated throughout the efficiency coefficient Nash-Sutcliffe [100] with available information from gauging stations between 1981 and 1998 [101]. In addition to the runoff generation, the groundwater reaction (baseflow) and human activities influence river discharges. Therefore, given the monthly basis, the baseflow was separated based on separating techniques from the time series of stream flows [102]. Due to the inclusion of human activities that can improve the simulation of monthly discharges according to Veldkamp et al. [103], a monthly discharge from the urban use was added. This discharge was a function of the population per year, the rate of population increase (11,000 inhabitants/year [32]), and a discharge rate of 75\% of water supply ( $90 \mathrm{~L} / \mathrm{inhabitant/day).}$

To forecast PGR in 2050, the scenarios proposal regards (a) current annual climate conditions, (b) moderate concentrations of greenhouse gases, and (c) extreme concentrations of greenhouse gases. The second and third scenarios are associated with variations in rainfall and temperature according to the RCP 4.5 and RCP 8.5 models of climate change [104]. These scenarios were estimated using the Max Planck Institute Earth System Model (MPI-ESM) [49,105].

In step 7, the groundwater recharge volumes were estimated for each year $(1986,2003,2017$, and 2050). The variation in potential groundwater recharge $\triangle P G R_{T-t}$ (Equation (1)) between years $T$ and $t$ was determined as a function of the potential groundwater recharge volume $P G R_{i j}$ of the pixel $i$ in month $j$.

$$
\Delta P G R_{T-t}=\sum_{i=T 1}^{T 12} P G R_{i j}-\sum_{i=t 1}^{t 12} P G R_{i j}
$$

\section{Results and Discussion}

\subsection{Supervised Classification}

Figure 3a shows a true-color image of the study zone where one can see a wide range of spectral signature as a function of the cover land. However, another type of band composition allowed for detecting specific land covers in a more differentiated manner (phase 1). For example, the false-color composition 234 (Figure 3b) highlights the differences between vegetation and urban area, as well as among several types of vegetation. Figure $3 \mathrm{c}$ shows a 345 composite image that was useful to differentiate between agricultural and natural vegetation [60]. All the selected satellite images satisfied a cloud cover lower than $20 \%$.

In addition to composite images, other materials were necessary in order to define training sites for supervised classification. The orthophotos obtained for 1995 and 2007 provided certainty about the land cover in past times because of its higher resolution concerning those from the satellite. For example, Figure 3d,e show how the construction of urban infrastructure followed the pattern drawn for different types of vegetation found in the composite images of 1986.

Based on the spectral signatures of the training sites, an analysis of separability was carried out using the transformed divergences, resulting in separability values of 1829 to 2000 units. These values are acceptable according to Richards and Jia [106]. The lowest separability value (1829) belongs to the urban/bare soil areas.

Urban growth is mostly observed in the southwestern portion of the municipality bordering the Pacific Ocean and toward the southeastern portion where the El Veladero Protected Natural Area is located. Further, urban growth appears to follow the pathway of the main roadways that connect Acapulco with central Mexico (Figure 4). 

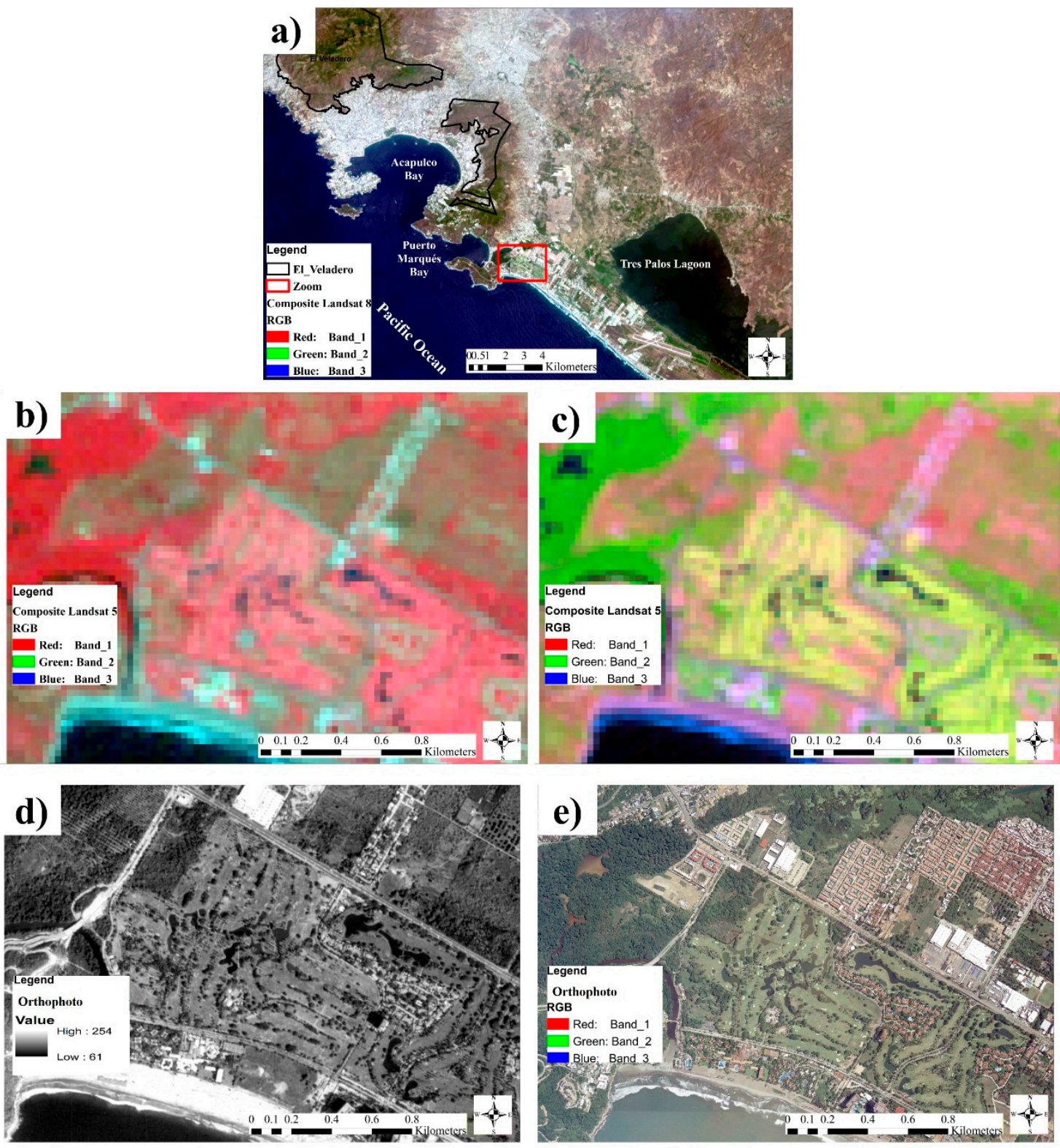

Figure 3. (a) True-color composite image, (b) Landsat 5, 1986, bands 234 at zoom, (c) Landsat 5, 1986, 345 at zoom, (d) Orthophoto 1995 1:20,000 at zoom, (e) Orthophoto, 2007, 1:10,000 at zoom.

Overall, most of the LUCC is associated with an increase in the urban area (Table 4). From 1986 to 2017, Acapulco expanded its urban zone to more than double its original size, mostly at the expense of agricultural areas. Further, the forest area decreased by $2 \%$. Some forest areas were displaced by agriculture, although not a significant amount.

Table 4. Land-use from 1986 to 2050 of Acapulco de Juárez.

\begin{tabular}{ccccccc}
\hline Use $\left.\mathbf{( k m}^{2}\right)$ Year & $\mathbf{1 9 8 6}$ & $\mathbf{\%}$ & $\mathbf{2 0 0 3}$ & $\mathbf{\%}$ & $\mathbf{2 0 1 7}$ & $\mathbf{\%}$ \\
\hline Forest & 1066.7 & 62 & 1083.9 & 63 & 1042.3 & 60 \\
Crops & 522.7 & 30 & 438.5 & 25 & 455.7 & 26 \\
Urban & 63.2 & 4 & 129.7 & 8 & 152.7 & 9 \\
Water & 74.1 & 4 & 74.6 & 4 & 76.0 & 4 \\
\hline
\end{tabular}



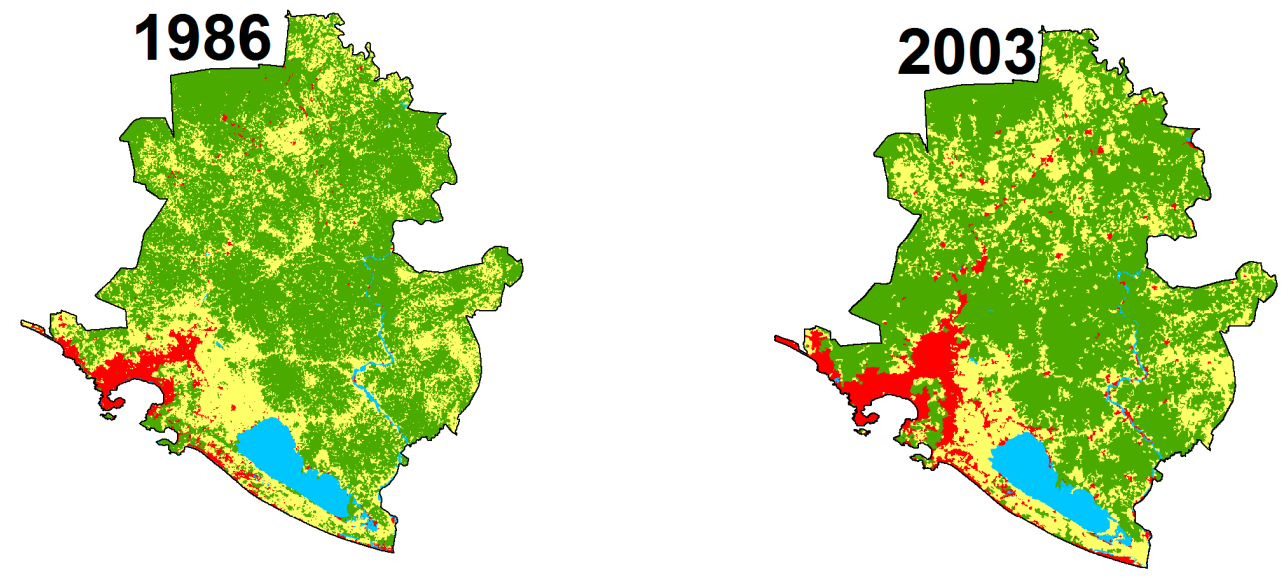

\section{7}
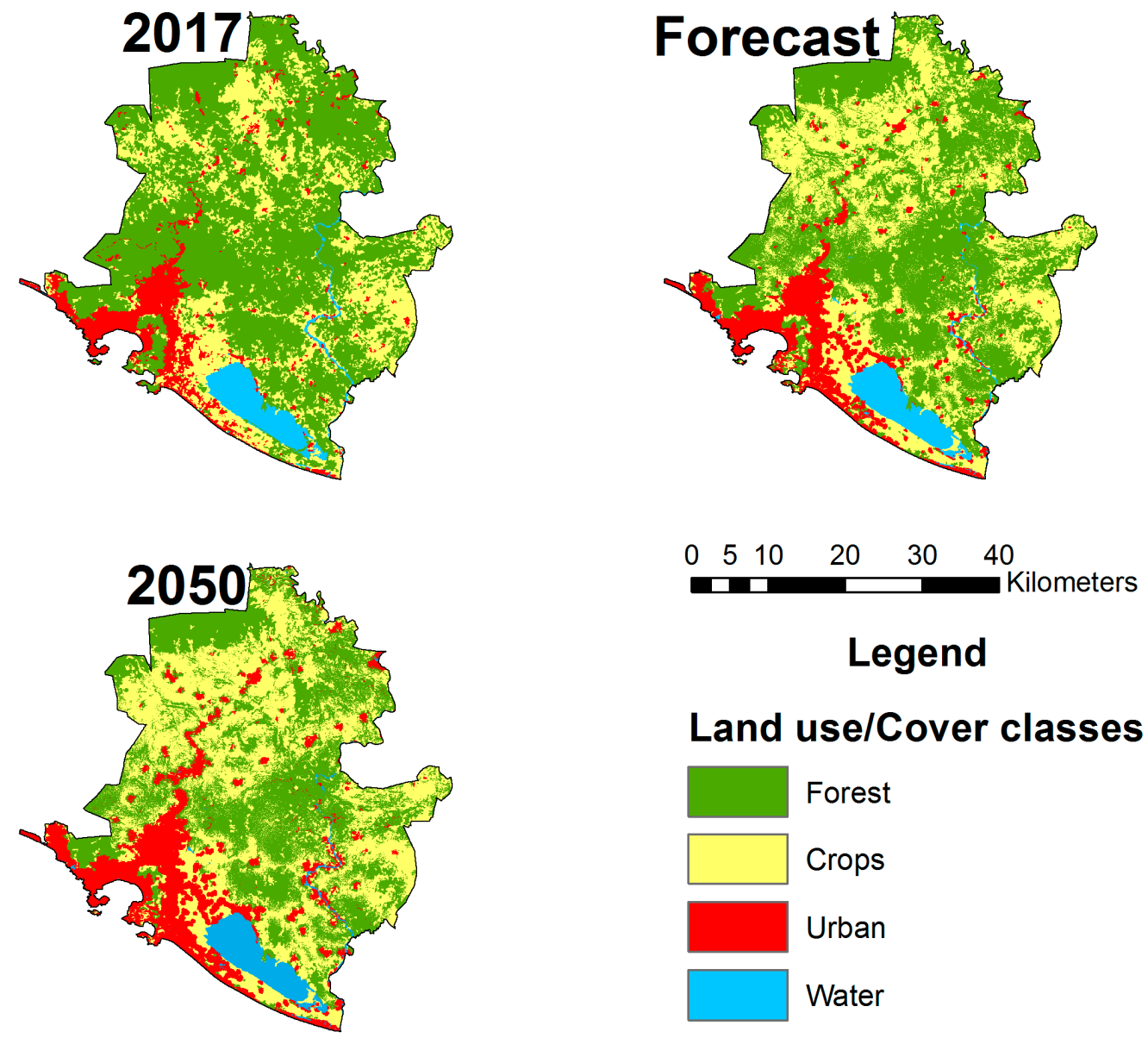

\section{Land use/Cover classes}

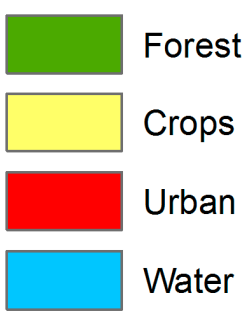

Figure 4. Supervised classification of Acapulco de Juárez 1986-2050.

The overall decrease in agricultural areas might be attributed to the low agricultural productivity of the region in comparison to the tourism sector. These changes imply an increase in the impermeable surface. However, no perceptible changes to the water bodies of the Papagayo River and Tres Palos Lagoon can be distinguished.

\subsection{Forecasting of Land-Use Change and Validation}

After the land-uses were determined for 1986, 2003, and 2017, the relationships between the LUCC and potentially explanatory variables were evaluated according to Cramer's V test. The urban 
infrastructure, climate and orographic variables were strongly related to LUCC, with V values greater than 0.28 and mostly greater than 0.4 (Table 5). The slope had the strongest relationship with land-use change, followed by the temperature.

Table 5. Evaluation of the explanatory variables with the Cramer V test.

\begin{tabular}{ccc}
\hline Explanatory Variables & Crops-Urban & Forest-Urban \\
\hline Distance to urban centers & 0.423 & 0.320 \\
Distance to roads & 0.288 & 0.288 \\
Slopes & 0.547 & 0.547 \\
Temperature & 0.537 & 0.537 \\
Precipitation & 0.547 & 0.510 \\
Digital model of elevation & 0.510 & 0.508 \\
\hline
\end{tabular}

To generate a predictive model of LUCC, which was first verified for 2017, a probabilistic Markov chain approach was used considering the land-use classifications in 1986 and 2003. In Figure 4, similarity can be observed between the current land-use map of 2017 and the forecasted land-uses by the model. The growth rate from 1986 to 2017 was about $2.88 \mathrm{~km}^{2} /$ year for the urban zone, whilst the decrease rates for forest and crops were 0.78 and $2.16 \mathrm{~km}^{2} /$ year, respectively (Table 6). The underestimated 3\% in LUCC for agricultural use (the northern portion in Figure 4) is likely because the crop area was relatively constant from 2003 to 2017.

Table 6. Comparison between current land-use surface for 2017 and forecasting for 2017 and 2050.

\begin{tabular}{|c|c|c|c|c|c|c|c|}
\hline Use & $\begin{array}{c}\text { Current } \\
2017\left(\mathrm{~km}^{2}\right)\end{array}$ & $\%$ & $\begin{array}{l}\text { Forecasting } \\
2017\left(\mathrm{~km}^{2}\right)\end{array}$ & $\%$ & $\begin{array}{c}\text { Difference } \\
\left(\mathbf{k m}^{2}\right)\end{array}$ & $\begin{array}{l}\text { Forecasting } \\
2050\left(\mathrm{~km}^{2}\right)\end{array}$ & $\%$ \\
\hline Forest & 1042.3 & 60 & 1073.0 & 62 & 30.7 & 1017.0 & 59 \\
\hline Crops & 455.7 & 26 & 393.5 & 23 & -62.2 & 366.6 & 21 \\
\hline Urban & 152.7 & 9 & 185.6 & 11 & 32.9 & 268.1 & 16 \\
\hline Water & 76.0 & 4 & 76.7 & 4 & 0.7 & 74.6 & 4 \\
\hline
\end{tabular}

In the validation of the predictive model of land-uses for 2017, an area under the ROC curve (AUC) of $86 \%$ was observed, which was higher than the $71 \%$ minimum recommended by Pontius [77]. Furthermore, the Kappa value of 0.85 confirmed that the model adequately predicted the change in the areas of land-use [77].

Given the satisfactory results of the model, LUCC was also estimated for 2050. Table 6 shows that the growth rate of urban use between 2017 and $2050\left(2.5 \mathrm{~km}^{2} /\right.$ year $)$ remains slightly below that of the former period. The existing urban area gets expanded toward the northern and northwestern part of Acapulco, mainly at the expense of agricultural areas and, to a lesser extent, forest areas.

Urban development seems to follow a north-south trend along the federal highway to central Mexico. New urban settlements also appear near water bodies, mainly between the Papagayo River and Tres Palos Lagoon. Along the coastline, a thin black line of urban settlements can be observed to extend from one extreme to the other.

The tendencies in LUCC for 2050 are similar to those of the previously analyzed 31-year period. From 1986 to 2017, the forest area decreased by $2 \%$ and the agricultural area by $4 \%$. Meanwhile, the urban area grew by 5\%. According to the predictions, from 2017 to 2050, the forest area will lose more than $1 \%$ (around $24 \mathrm{~km}^{2}$ ), and the agricultural area will lose $5 \%$. Notably, the urban area will gain $7 \%$.

\subsection{Current and Future Potential Groundwater Recharge}

As is mentioned in the Method, the conceptual and distributed hydrologic model must be validated with field measures. In this context, the validation of surface runoff through the information provided by gauge stations would allow for assuming the coherence among the rest of the hydrologic flows. 
Figure 5a shows a comparative view of the hydrographs with the simulated and observed surface monthly runoff volume corresponding to the contributing catchment area of gauge station 19,018 (see Figure 1). According to several criteria [105], the goodness of fit for the model is satisfactory because it provides an adjusted coefficient of determination equal to 0.768 , and a Nash-Sutcliffe coefficient of 0.767 . In annual terms, the average simulated runoff volume was equal to $172.7 \mathrm{hm}^{3} /$ year (with a standard deviation of $57.2 \mathrm{hm}^{3} /$ year) whilst the average observed runoff volume was equal to $173.5 \mathrm{hm}^{3} /$ year (with a standard deviation of $90.0 \mathrm{hm}^{3} /$ year). The estimated annual runoff volume for 1986, 2003 and 2017 was $161.61 \mathrm{hm}^{3}, 172.1 \mathrm{hm}^{3}$ and $175.28 \mathrm{hm}^{3}$, respectively. Although the accuracy of the estimated runoff could be improved by increasing the number of elements classified relative to land cover (for instance, different types of forest vegetation instead of just one), it is relevant to regard that the more classes that are included in the supervised classification, the smaller the difference between the spectral signatures of classes could be.
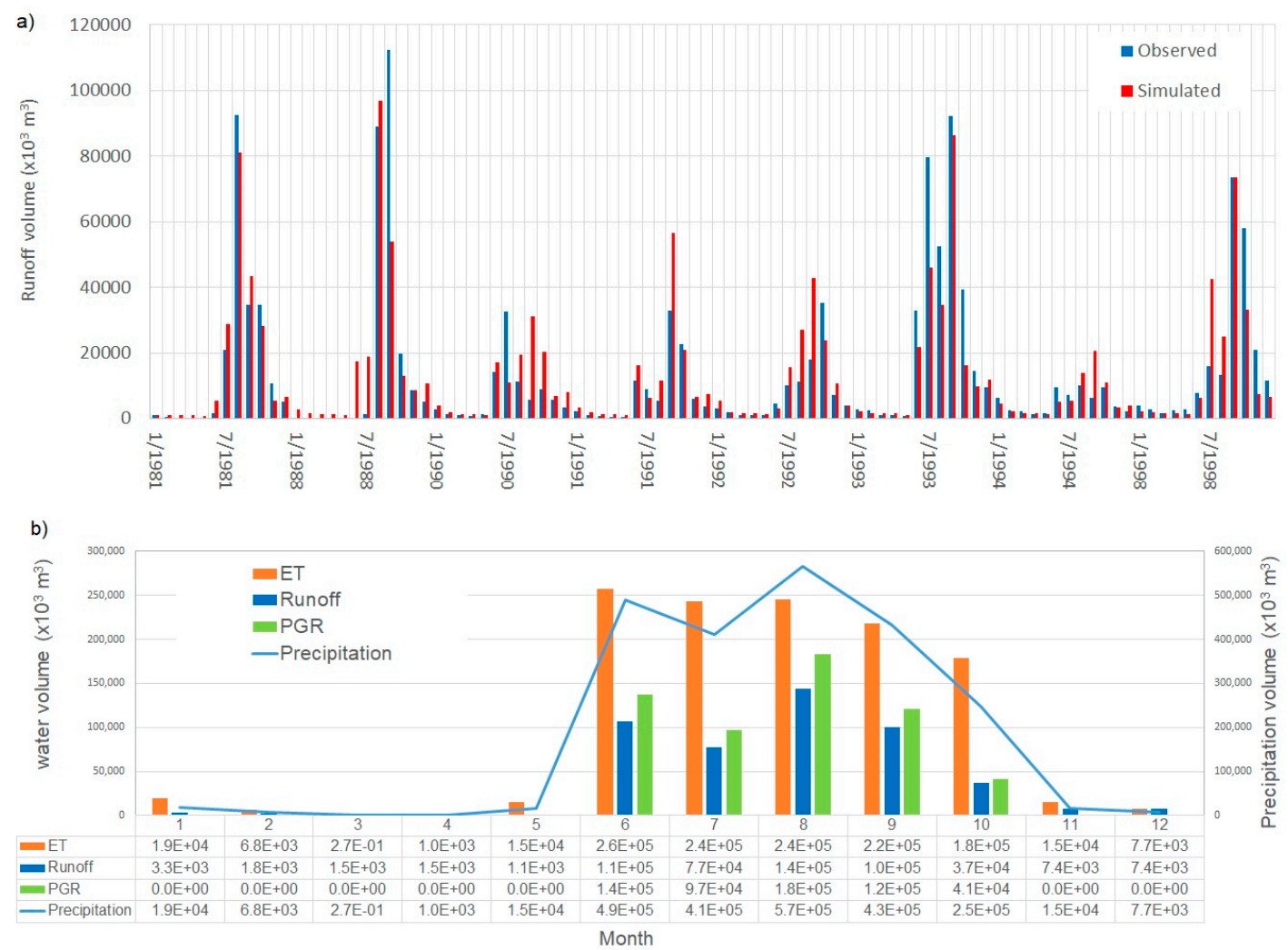

Figure 5. (a) Observed and simulated monthly surface runoff volume; (b) average monthly volume of precipitation, evapotranspiration ET, surface runoff and potential groundwater recharge PGR.

According to the model results (Figure 5b, and attached as Supplementary Materials), the annual mean volumes presented values of $2211 \mathrm{hm}^{3}$ (with a standard deviation of $510 \mathrm{hm}^{3}$ ) for precipitation, $1207 \mathrm{hm}^{3}$ (with a standard deviation of $136.7 \mathrm{hm}^{3}$ ) for evapotranspiration, and $460 \mathrm{hm}^{3}$ (with a standard deviation of $220 \mathrm{hm}^{3}$ ) for surface runoff. PGR showed an annual mean volume of $599.75 \mathrm{hm}^{3}$ (with a standard deviation of $293.3 \mathrm{hm}^{3}$ ), which depicts between $10 \%$ and $36 \%$ of the annual precipitation volume. The official information reports a proportional recharge of $18 \%$ approximately [52,53], and remains in the estimated range. In comparison with other studies, Moeck et al. [107] provide the relationship between the recharge rate and several variables around the globe. One of these variables, the Aridity Index (ETp/P), shows that recharge rates $>500 \mathrm{~mm} /$ year from more than 5000 locations are associated with Aridity Index values between 0.8 and 1.4, approximately. In the present study case, the mean recharge rate of $740 \mathrm{~mm} /$ year is coherent with the mean Aridity Index resulting from the model, equal to 1.26 . 
Visually, few significant changes in the spatial distribution of PGR are observed (Figure 6) from 1986 to 2003. Nevertheless, in 2017 the PGR in the northern and northeastern parts of the municipality shows a clear decrease as a result of the lost forest area $\left(41.6 \mathrm{~km}^{2}\right)$. The most significant decrease in potential groundwater recharge over the initial 31-year period is located around the Tres Palos Lagoon and near the Pacific Ocean. This may be attributed to the transition of several highly permeable areas (forest and agricultural uses) to urban uses.
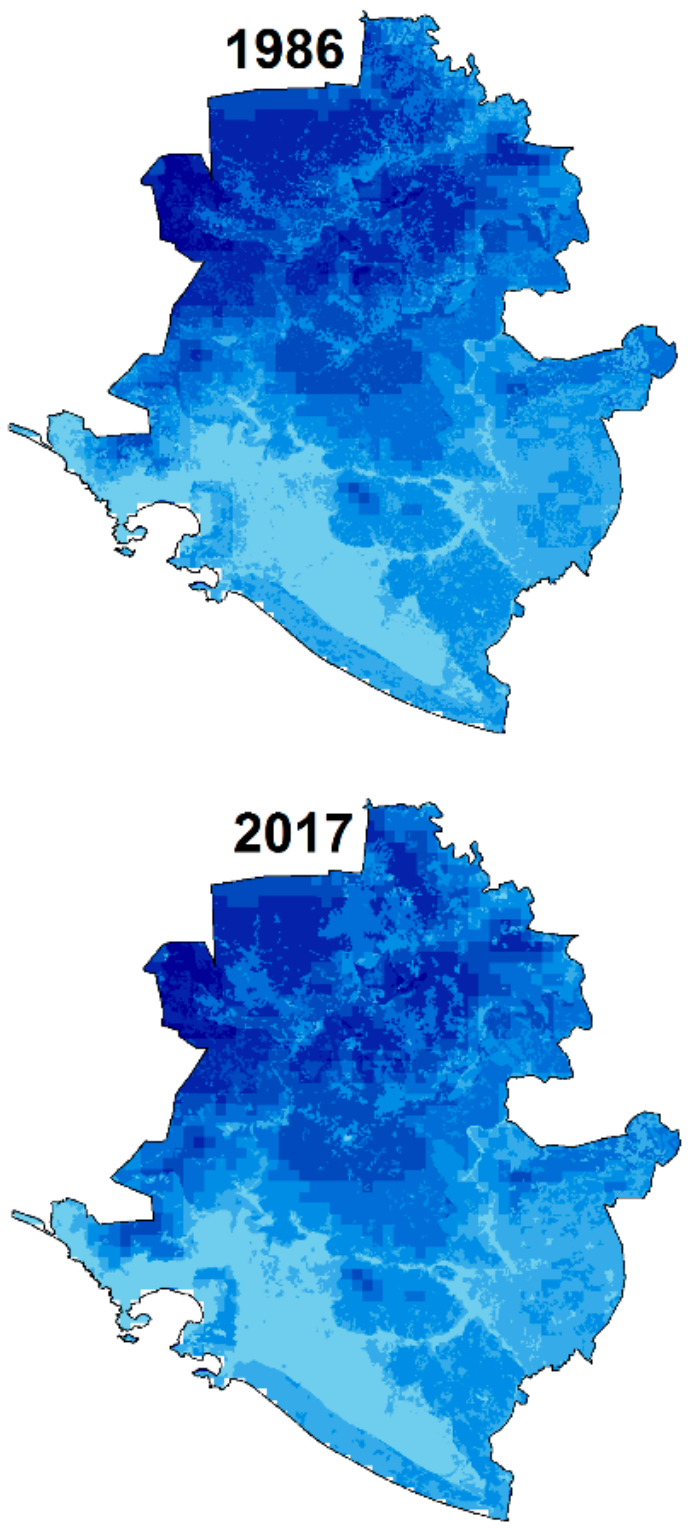
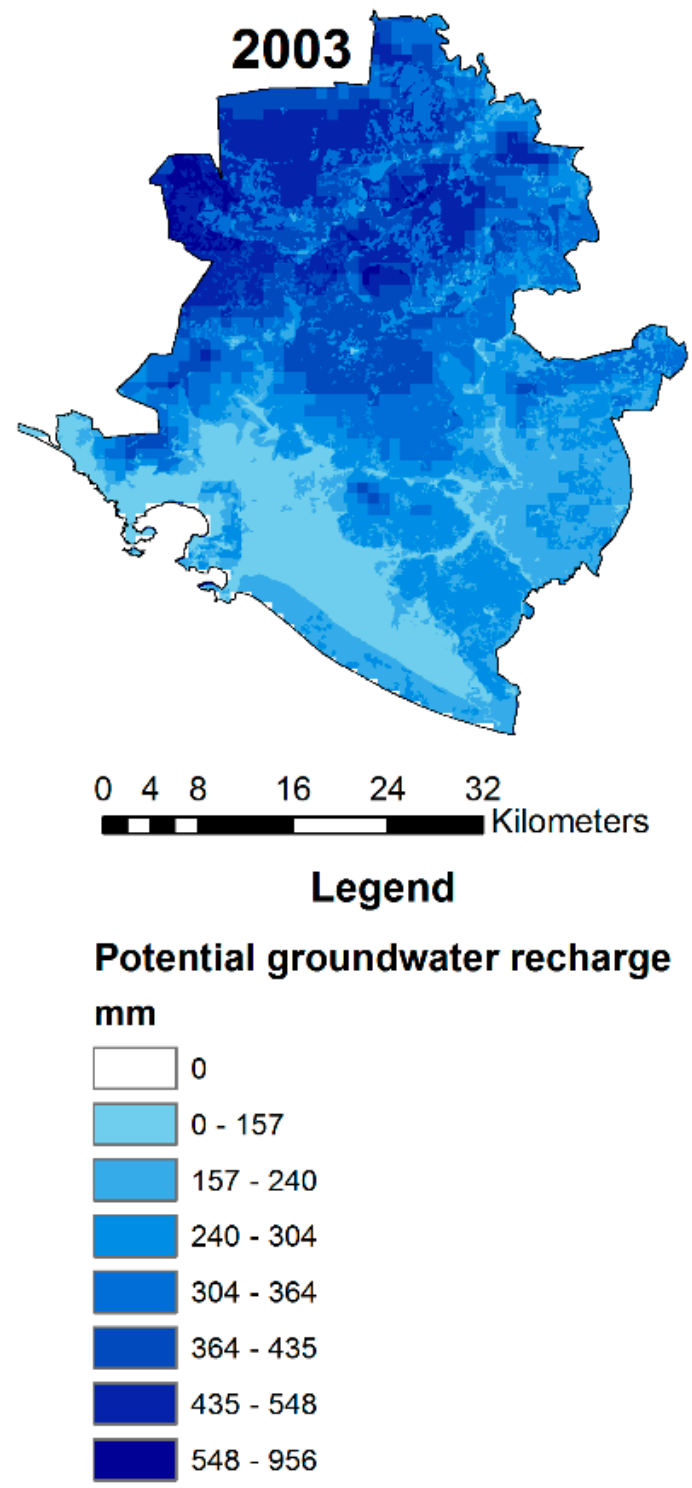

Figure 6. PGR depth 1986-2017.

The estimated PGR for 2050, given current climate conditions (Figure 7a), decreased mainly due to the expansion of the urban settlements bordering the Papagayo River and toward the extreme northern part of the municipality. Under these conditions, from 2017 to 2050, PGR is expected to decrease considerably by $65.97 \mathrm{hm}^{3}$, or almost 10 times compared to the 1986-2017 period (Table 7). 

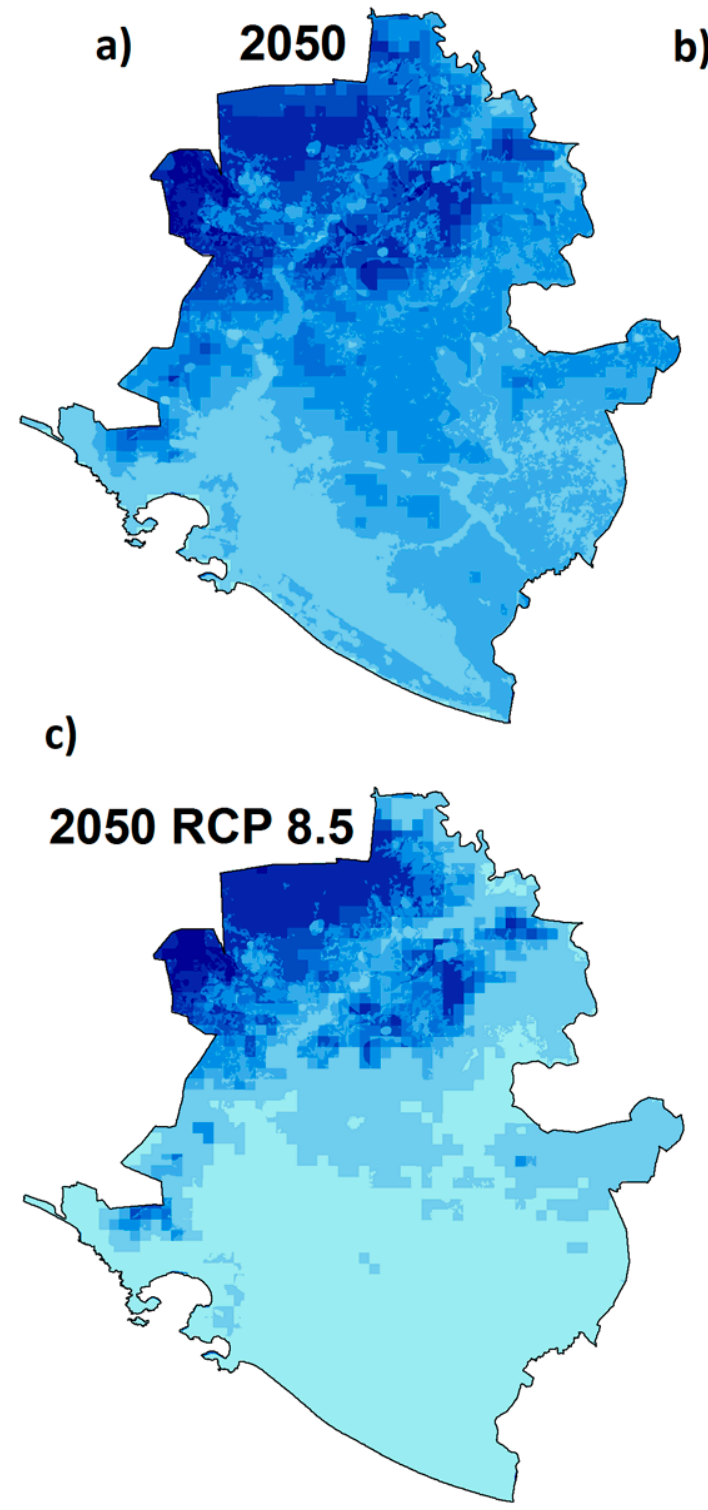

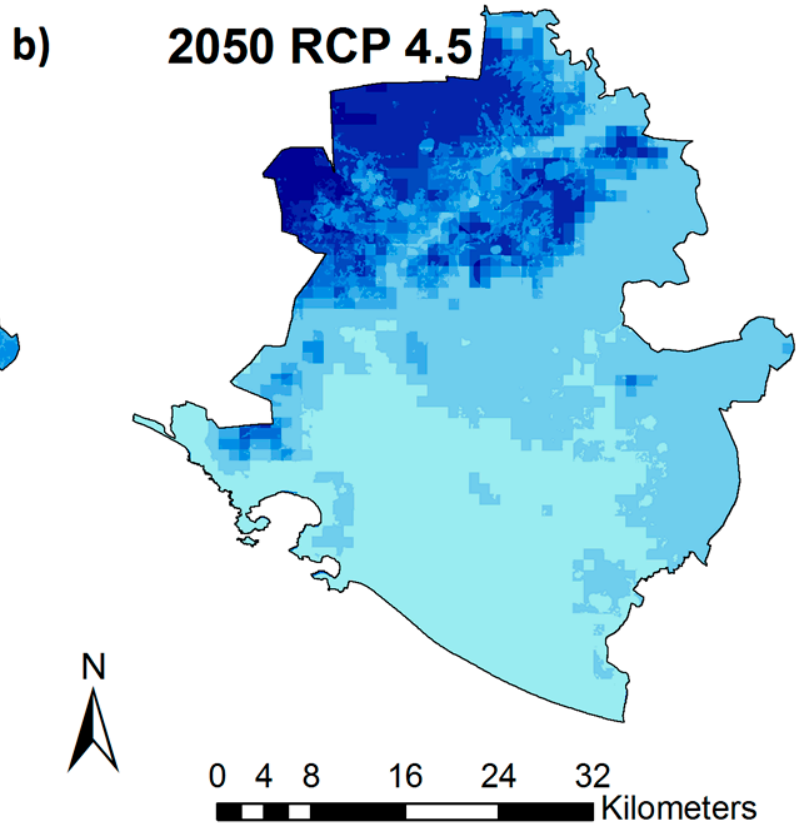

\section{Legend}

Potential groundwater recharge $\mathrm{mm}$

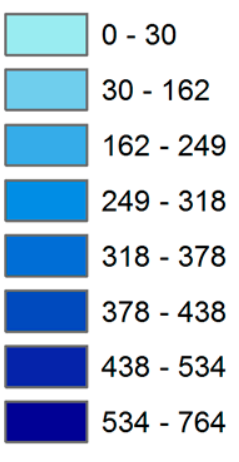

Figure 7. Potential groundwater recharge for 2050 with climatic variables; (a) current weather conditions, (b) RCP 4.5 and (c) RCP 8.5 weather conditions predicted by the IPCC for 2050.

Table 7. PGR variation.

\begin{tabular}{cccccc}
\hline Year & $\begin{array}{c}\text { A Groundwater } \\
\text { Recharge } \mathbf{( h m}^{\mathbf{3}} \mathbf{)}\end{array}$ & $\begin{array}{c}\text { B Variation } \\
\mathbf{( h m}^{\mathbf{3}} \mathbf{)}\end{array}$ & $\begin{array}{c}\text { C Cumulative } \\
\text { Variation } \mathbf{( h m}^{\mathbf{3}} \mathbf{)}\end{array}$ & $\begin{array}{c}\text { D Proportional } \\
\text { Variation (\%) }\end{array}$ & $\begin{array}{c}\text { E Annual Proportional } \\
\text { Variation } \mathbf{( \% )}\end{array}$ \\
\hline 1986 & 512.26 & - & - & - & - \\
2003 & 510.50 & 1.76 & 1.76 & 0.34 & 0.02 \\
2017 & 505.15 & 5.34 & 7.10 & 1.05 & 0.07 \\
2050 & 439.18 & 65.97 & 73.07 & 13.06 & 0.39 \\
2050 RCP4.5 & 264.04 & 241.11 & 248.22 & 47.73 & 1.44 \\
2050 RCP8.5 & 238.96 & 266.18 & 273.30 & 52.69 & 1.59 \\
\hline
\end{tabular}

Note: Column B is estimated as the difference between each value from A. Column $C$ is the cumulative value of $B$. Column D is the quotient of $\mathrm{B}$ and $\mathrm{A}$ columns. Column $\mathrm{E}$ is the quotient of column $\mathrm{D}$ and the length of the period.

Under the RCP 4.5 and 8.5 climate change scenarios, the PGR estimated for 2050 decreases even more dramatically across more than half of the municipality (Figure $7 \mathrm{~b}, \mathrm{c}$ ). This can mainly be attributed to the forecasted changes in temperature and rainfall (Table 8). Although the two climate scenarios show similar behavior, the RCP 8.5 scenario shows a greater loss of groundwater recharge, corresponding with an annual decrease of more than $100 \mathrm{hm}^{3}$, mostly as a result of the annual decrease 
in rainfall depth of $150 \mathrm{~mm}$ in the southern part of the municipality. With respect to the temperature, a significant increase of about $3^{\circ} \mathrm{C}$ is observed across nearly half of the municipality in both scenarios, compared to 1970-2000. This increase would result in greater evapotranspiration and, consequently, decreased groundwater recharge across more than half of the municipality.

Table 8. Temperature and precipitation for the municipality of Acapulco [48].

\begin{tabular}{ccccc}
\hline Scenario & Year & $\mathbf{C O}_{\mathbf{2}} \mathbf{e q}(\mathbf{p p m})$ & $\begin{array}{c}\text { Average } \\
\text { Temperature }\left({ }^{\circ} \mathbf{C}\right)\end{array}$ & Annual Precipitation (mm) \\
\hline Current & 2050 & $* 379$ & $20.0-27.7$ & $1120-1663$ \\
RCP 4.5 & 2050 & 650 & $20.6-30.8$ & $1001-1839$ \\
RCP 8.5 & 2050 & 1350 & $21.0-31.4$ & $987-1818$ \\
\hline \multicolumn{5}{c}{${ }^{*}$ Nackisenivic et al. $[108]}$.
\end{tabular}

The loss of groundwater recharge from 1986 to 2003 is only one-third of the loss from 2003 to 2017. The loss from 2003 to 2017 is mostly due to the 3\% decrease in the forest area. However, the decrease in groundwater recharge from 2017 to $2050\left(241 \mathrm{hm}^{3}\right)$ is estimated to be 9 to 37 times greater than that from 1986 to 2017. This can be largely attributed to changing climate conditions and, secondly, to urban expansion over areas of high permeability. The contribution of LUCC to the reduced potential groundwater recharge is between $25 \%$ and $27 \%$.

Over the analyzed period, the largest infiltration area is associated with forest areas in the northeastern part of the municipality. Groundwater recharge generally decreases in the direction of the Pacific Ocean. Further, a decrease in groundwater recharge is observed in the lower part of Acapulco Bay, along the coastline, and around Tres Palos Lagoon and Puerto Marqués Bay.

Recapitulating the effect of LUCC on the PGR, there still are some elements to analyze. Considering that the urban use of land constituted 5\% of the total ground surface from 1986 to 2017 and $7 \%$ from 2017 to 2050, this seems to be an insufficient change to account for a PGR variation of almost 10 times in the same periods. However, an evaluation regarding both the change of other land uses and the location of those changes is necessary. Regarding the term elasticity, defined as the rate of the proportional variation in time $i$ of the PGR $\left(\frac{\Delta P G R_{i, i+1}}{P G R_{i}}\right)$ related to the proportional variation in time $i$ of LUCC for forest and crops $\left(\frac{\Delta(F+C)_{i, i+1}}{(F+C)_{i}}\right)$, it is possible to appreciate a change of $24 \%$ in PGR for each unit of variation in LUCC from 1986 to 2017. In contrast, from 2017 to 2050, the elasticity is $170 \%$, which also denotes a sensitivity in LUCC associated with the loss of both crops and forests.

On the other hand, it was estimated that the loss of PGR (assuming the PGR image of 1986) corresponds to the LUCC associated with urban use for 2017 and 2050. The $89.5 \mathrm{~km}^{2}$ of urban-use land increased in 2017, leading to a loss of $23 \mathrm{hm}^{3} / \mathrm{km}^{2}$ in PGR, whilst the $115.4 \mathrm{~km}^{2}$ increase in urban-use land in 2050 (in relation with 2017) leads to a loss of $29 \mathrm{hm}^{3} / \mathrm{km}^{2}$ in PGR. That means the LUCC matters, but also where this change is generated. In this context, Figure 8 shows the urban LUCC between 1986, 2017 and 2050 as related to the PGR relative to 1986, classified in quartiles. From the urban LUCC in 2017,7 of the $89.56 \mathrm{~km}^{2}(8 \%)$ are located in the 4 th quartile (Q4) of the PGR relative to the 1986 image (375-685 mm/year). For 2050, the urban LUCC located in the same quartile reaches $15 \mathrm{~km}^{2}(13 \%$ of the increase).

The information before-mentioned leads to a series of possible strategies in sustainable water resource management. For instance, in the case of the urban LUCC in the quartile of higher PGR (Q4), it is possible to establish a Payment for Hydrological Environmental Services (PHES) as compensation to preserve areas of hydrologic importance. The PHES has been implemented in Ecuador, Nicaragua, and Mexico, e.g., the government of Mexico paid landowners 2109 USD $/ \mathrm{km}^{2} /$ year for hydrologic conservation areas in 2019 [109]. A second strategy refers to using the PGR image classified in quartiles as a weighted input of a Multicriteria Analysis to minimize the urban land-use growth in the context of Urban Planning and Management [110-113]. The proposal of these strategies becomes more relevant 
every time as the population, and consequently its water requirements, grow immeasurably (by 2050, the population growth in Acapulco will reach just over 11,000 inhabitants/year).

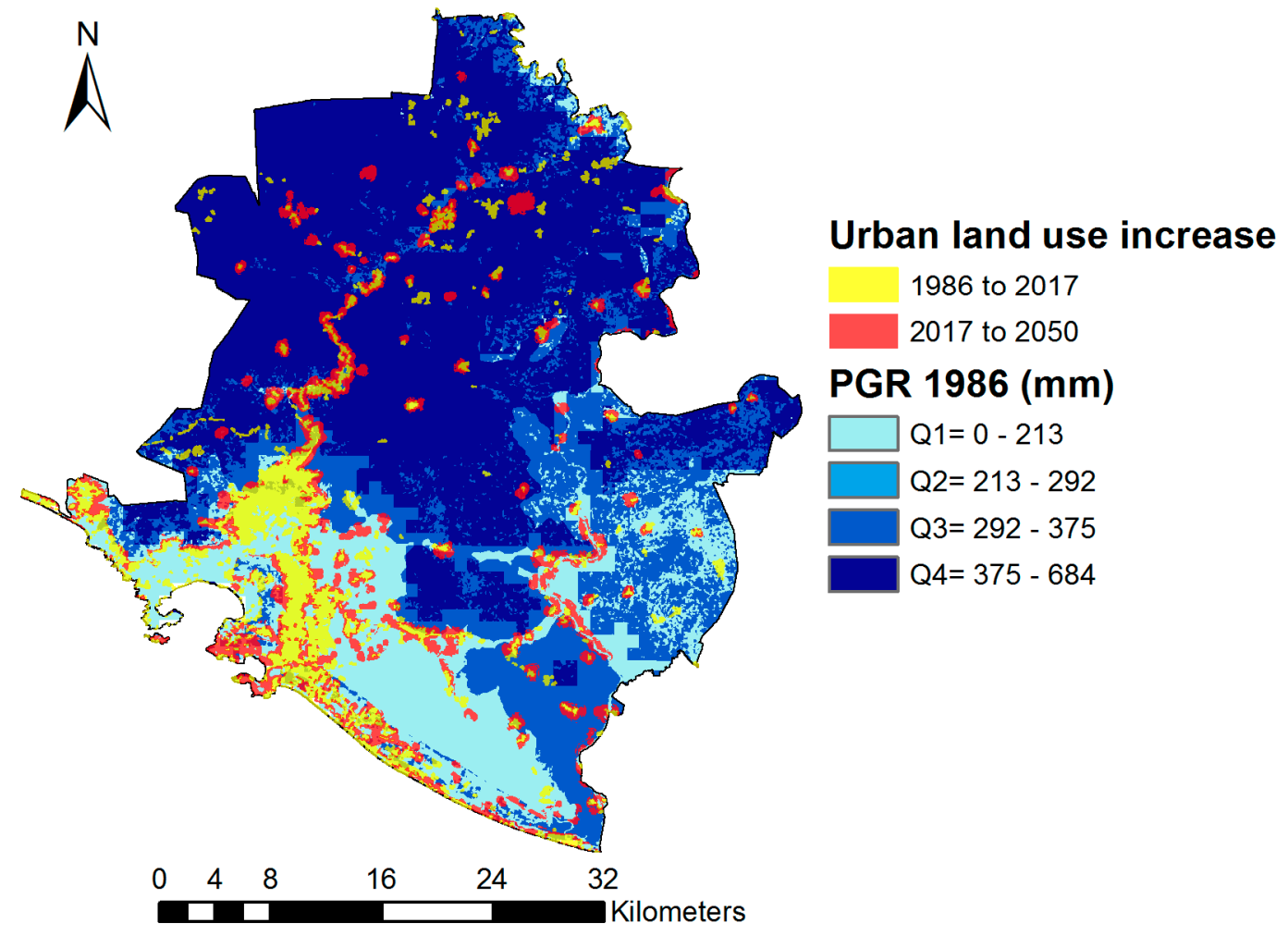

Figure 8. Urban LUCC for 2017 and 2050 is located in classified PGR classes.

\section{Conclusions}

The present work analyzed not just the effect of the LUCC on the potential groundwater recharge (PGR), but also the combined effect regarding climate change. Although it is suggested to assess this kind of effect as a function of the location, altitude, and other climatic characteristics, as expected for a sub-tropical region, the climate change showed a higher proportional impact than the LUCC.

One of the modeling keys for projecting the impact on PGR throughout the period was keeping the driver variables as simple as possible in the forecasting of both LUCC and PGR estimation. On one hand, the classification of land cover into a few groups allowed the elements in each group to be more similar in their potential capacity for infiltration, whereas the difference from other groups becomes higher. On the other hand, a distributed model for PGR estimation is kept independent of the vertical flows among the cells, so the global value is the sum of every flow instead of the result of a combination of attributes in a whole area. Besides, the use of empirical rather than physically-based models to obtain evapotranspiration meant the PGR could be estimated by variables associated with climate change projection, assuming the rest of the variables covary with temperature. Otherwise, the model would increase the complexity of inferring the variation in other physical variables, such as specific humidity, among others.

For the assessment of the above-mentioned effects, a platform in a Geographic Information System environment provided a powerful tool in the same way, as it requires the variables to be in a distributed format. In this case, remote sensing was demonstrated to be an adequate source for forecasting LUCC over time. Nevertheless, it still needs specific assistance in order to identify accurately training sites. Besides the knowledge and expertise of the researcher concerning the study zone, other complementary materials supported this task: orthophotos for older periods and new developments, and Google Earth for recent ones. 
One notable finding is the complex dynamics of LUCC over time. For instance, and opposite to what was expected in the study zone, the forest area slightly increased over the first period (1986 to 2003) but decreased in the second period (2003 to 2017). The agricultural area slightly increased in the second period after decreasing in the first period.

In addition to the classified images, the LUCC required some explanatory variables to generate the forecasting. The one with more influence in the study area was the slope, owing to rugged geography. Urban growth does not occur entirely in areas with higher slopes. Besides, high altitude, low temperature and high precipitation converge in the study zone with low settlements. This analysis could be improved by considering additional socioeconomic variables (for example, the price per $\mathrm{m}^{2}$ of residential and marginal areas), as suggested by Yalew et al. [16]. However, the satisfactory LUCC forecasting showed that its direction and magnitude have direct and indirect socio-economic implications, especially considering the constant growth of the population and tourism sector in Acapulco de Juárez.

Once the LUCC was successfully validated through a Cramer's test and the area under the curve ROC was determined, the applied distributed model to estimate the potential groundwater recharge provided satisfactory results, according to observed measures.

According to the LUCC results, the decrease in the groundwater recharge due to climate change could be even more than three times the one associated with the urban land-use growth. In any case, water security is likely threatened in the medium-term, and thee is also an increase in both flooding risk and marine intrusion [1]. In other words, the decrease in groundwater recharge as a result of LUCC is especially relevant for coastal municipalities, because of the increased associated risk of flooding and marine intrusion [27].

In the groundwater recharge evaluation, under moderate and severe climate change scenarios (RCP 4.5 and 8.5, respectively), the loss of groundwater recharge could be up to 37 times higher than the one estimated if current climate conditions continue. An increased temperature of $3{ }^{\circ} \mathrm{C}$ could generate a $28 \%$ increase in evapotranspiration. Accordingly, between $0.01 \%$ and $0.25 \%$ of the potential groundwater recharge per $\mathrm{km}^{2}$ associated with land-use change to urban use is expected to be lost by 2050 .

Furthermore, the estimated variation in potential groundwater recharge remains consistent, despite uncertainties associated with the selected hydrological model. This is only because these possible inaccuracies could be systematic and directly proportional to the groundwater baseline estimated for the initial study year.

The potential groundwater recharge was projected for different climatological conditions. We observed a greater influence of climate change than LUCC on this variation. This confirmed that both evapotranspiration increases and recharge decreases as the temperature increases due to climate change. Therefore, this work provides a methodology useful to estimating impacts on water security, mostly in low-latitude regions with high urban growth around the world.

Supplementary Materials: The following are available online at http://www.mdpi.com/2073-445X/9/10/364/s1. The Land/Cover Use and Potential Groundwater Recharge imagery used to support the findings of this study are included within the supplementary information file(s). Modules used to estimate results on the GIS platform is available for download on http://idrisi.uaemex.mx/distribucion/apl-emergy.

Author Contributions: For research articles conceptualization, C.R.F.; methodology, J.G.-M. and C.R.F.; software, C.R.F., and M.A.G.-A.; validation, C.R.F., M.A.G.-A., and J.G.-M.; investigation, M.A.G.-A. and J.G.-M.; resources, M.A.G.-A.; review and editing S.E.S.-G. and M.L.S.-R. All authors have read and agreed to the published version of the manuscript.

Funding: This research was funded by Consejo Nacional de Ciencia y Tecnología (CONACyT) and Centro de Ciencias de Desarrollo Regional (CCDR) of Universidad Autonoma de Guerrero.

Acknowledgments: The authors gratefully acknowledge the support received from Consejo Nacional de Ciencia y Tecnología (CONACyT) by the financial support for human resources development. Authors would like to thank the reviewers for the comments that have improved the present work.

Conflicts of Interest: The authors declare no conflict of interest. 


\section{References}

1. Brauman, K.A.; Freyberg, D.L.; Daily, G.C. Impacts of land-use change on groundwater supply: Ecosystem services assessment in Kona, Hawaii. J. Water Resour. Plan. Manag. 2014, 141, 1-11. [CrossRef]

2. Calzada, L.; Meave, J.; Bonfil, C.; Figueroa, F. Land at risk: Land use/land cover in two contrasting tropical dry regions of Mexico. Appl. Geogr. 2018, 99, 22-30. [CrossRef]

3. Mukherjee, S.; Bebermeier, W.; Schütt, B. An overview of the impacts of land use land cover changes (1980-2014) on urban water security of Kolkata. Land 2018, 7, 91. [CrossRef]

4. Sandoval, J.A.; Tiburan, C.L., Jr. Identification of potential artificial groundwater recharge sites in mount makiling forest reserve, philippines using GIS and analytical hierarchy. Appl. Geogr. 2019, 105, 73-85. [CrossRef]

5. Jacobson, C.R. Identification and quantification of the hydrological impacts of imperviousness in urban catchments: A review. J. Environ. Manag. 2011, 92, 1438-1448. [CrossRef]

6. Han, D.; Currell, M.J.; Cao, G.; Hall, B. Alterations to groundwater recharge due to anthropogenic landscape change. J. Hydrol. 2017, 554, 545-557. [CrossRef]

7. Dirckx, G.; Van Daele, S.; Hellinck, N. Groundwater Infiltration Potential (GWIP) as an aid to determining the cause of dilution of wastewater. J. Hydrol. 2016, 542, 474-486. [CrossRef]

8. Mosase, E.; Ahiablame, L.; Park, S.; Bailey, R. Modelling potential groundwater recharge in the Limpopo River Basin with SWAT-MODFLOW. Groundw. Sustain. Dev. 2019, 9, 100260. [CrossRef]

9. Yawson, D.O.; Adu, M.O.; Mulholland, B.; Ball, T.; Frimpong, K.A.; Mohan, S.; White, P.J. Regional variations in potential groundwater recharge from spring barley crop fields in the UK under projected climate change. Groundw. Sustain. Dev. 2019, 8, 332-345. [CrossRef]

10. Cui, Z.; Wu, G.; Huang, Z.; Liu, Y. Fine roots determine soil infiltration potential than soil water content in semi-arid grassland soils. J. Hydrol. 2019, 578, 124023. [CrossRef]

11. Quiroz, O.M.; Romanelli, A.; Lima, M.L. Fuzzy logic-based assessment for mapping potential infiltration areas in low-gradient watersheds. J. Environ. Manag. 2016, 176, 101-111. [CrossRef] [PubMed]

12. Hu, W.; Wang, Y.Q.; Li, H.J.; Huang, M.B.; Hou, M.T.; Li, Z.; She, D.L.; Si, B.C. Dominant role of climate in determining Spatio-temporal distribution of potential groundwater recharge at a regional scale. J. Hydrol. 2019, 578, 124042. [CrossRef]

13. Jinno, K.; Tsutsumi, A.; Alkaeed, O.; Saita, S.; Berndtsson, R. Effects of land-use change on groundwater recharge model parameters. Hydrol. Sci. J. 2009, 54, 300-315. [CrossRef]

14. Sun, D.; Yang, H.; Guan, D.; Yang, M.; Wu, J.; Yuan, F.; Jin, C.; Wang, A.; Zhang, Y. Science of the total environment the effects of land-use change on soil infiltration capacity in China: A meta-analysis. Sci. Total Environ. 2018, 626, 1394-1401. [CrossRef]

15. Marhaento, H.; Booij, M.J.; Hoekstra, A.J. Hydrological response to future land-use change and climate change in a tropical catchment. Hydrol. Sci. J. 2018, 63, 1368-1385. [CrossRef]

16. Yalew, S.G.; Pilz, T.; Schweitzer, C.; Liersch, S.; Van Der Kwast, J.; Van Griensven, A. Environmental modelling \& software coupling land-use change and hydrologic models for quantification of catchment ecosystem services. Environ. Model. Softw. 2018, 109, 315-328. [CrossRef]

17. Aburas, M.M.; Ahamad, M.S.; Omar, N.Q. Spatio-temporal simulation and prediction of land-use change using conventional and machine learning models: A review. Environ. Monit. Assess. 2019, 191, 205. [CrossRef]

18. Islam, K.; Rahman, M.F.; Jashimuddin, M. Modeling land use change using cellular automata and artificial neural network: The case of chunati wildlife sanctuary, bangladesh. Ecol. Indic. 2018, 88, 439-453. [CrossRef]

19. Noszczky, T. A review of approaches to land use changes modeling. Hum. Ecol. Risk Assess. 2019, 25, 1377-1405. [CrossRef]

20. Tarawally, M.; Wenbo, X.; Weiming, H.; Darlingto, T.M.; Biniyam, M.K. Land use/land cover change evaluation using land change modeler: A comparative analysis between two main cities in Sierra Leone. Remote Sens. Appl. Soc. Environ. 2019, 16, 100262. [CrossRef]

21. Jackson, T.J. Remote sensing of soil moisture: Implications for groundwater recharge. Hydrogeol. J. 2002, 10, 40-51. [CrossRef]

22. Bayabil, H.K.; Dile, Y.T.; Tebebu, T.Y.; Engda, T.A.; Steenhuis, T.S. Evaluating infiltration models and pedotransfer functions: Implications for hydrologic modeling. Geoderma 2019, 338, 159-169. [CrossRef] 
23. Li, K.Y.; Coe, M.T.; Ramankutty, N.; Jong, R.D. Modeling the hydrological impact of land-use change in West Africa. J. Hydrol. 2007, 337, 258-268. [CrossRef]

24. Zhang, L.; Wang, C.; Li, X.; Zhang, H.; Li, W.; Jiang, L. Impacts of agricultural expansion (1910s-2010s) on the water cycle in the songneng plain, northeast China. Remote Sens. 2018, 10, 1108. [CrossRef]

25. Zektser, I.S.; Everett, L.G. Groundwater Resources of the World and Their Use (UNESCO, Paris, 2004). Available online: http://unesdoc.unesco.org/images/0013/001344/134433e.pdf (accessed on 9 September 2020).

26. Siebert, S.; Burke, J.; Faures, J.M.; Frenken, K.; Hoogeveen, J.; Döll, P.; Portmann, F.T. Groundwater use for irrigation-A global inventory. Hydrol. Earth Syst. Sci. 2010, 14, 1863-1880. [CrossRef]

27. Kurylyk, B.L.; MacQuarrie, K.T.B. The uncertainty associated with estimating future groundwater recharge: A summary of recent research and an example from a small unconfined aquifer in a northern humid-continental climate. J. Hydrol. 2013, 492, 244-253. [CrossRef]

28. Döll, P. Vulnerability to the impact of climate change on renewable groundwater resources: A global-scale assessment. Environ. Res. Lett. 2009, 4, 35006. [CrossRef]

29. Ali, R.; McFarlane, D.; Varma, S.; Dawes, W.; Emelyanova, I.; Hodgson, G. Potential climate change impacts on the water balance of regional unconfined aquifer systems in south-western Australia. Hydrol. Earth Syst. Sci. 2012, 16, 4581-4601. [CrossRef]

30. Allen, D.M.; Cannon, A.J.; Toews, M.W.; Scibek, J. Variability in simulated recharge using different GCMs. Water Resour. Res. 2010, 46, W00F03. [CrossRef]

31. Crosbie, R.; Pickett, T.; Mpelasoka, F.; Hodgson, G.; Charles, S.; Barron, O. An assessment of the climate change impacts on groundwater recharge at a continental scale using a probabilistic approach with an ensemble of GCMs. Clim. Change 2013, 117. [CrossRef]

32. Dams, J.; Salvadore, E.; Van Daele, T.; Ntegeka, V.; Willems, P.; Batelaan, O. Spatio-temporal impact of climate change on the groundwater system. Hydrol. Earth Syst. Sci. 2012, 16, 1517-1531. [CrossRef]

33. Jackson, C.R.; Meister, R.; Prudhomme, C. Modelling the effects of climate change and its uncertainty on UK Chalk groundwater resources from an ensemble of global climate model projections. J. Hydrol. 2011, 399, 12-28. [CrossRef]

34. Holman, I.P.; Tascone, D.; Hess, T.M. A comparison of stochastic and deterministic downscaling methods for modeling potential groundwater recharge under climate change in East Anglia, UK: Implications for groundwater resource management. Hydrogeol. J. 2009, 17, 1629-1641. [CrossRef]

35. Serrat-Capdevila, A.; Valdés, J.B.; Pérez, J.G.; Baird, K.; Mata, L.J.; Maddock, T., III. Modeling climate change impacts—and uncertainty—on the hydrology of a riparian system: The San Pedro Basin (Arizona/Sonora). J. Hydrol. 2007, 347, 48-66. [CrossRef]

36. Bronstert, A. Rainfall-runoff modeling for assessing impacts of climate and land use change. Encyclopedia Hydrol. Sci. 2006, 11, 15. [CrossRef]

37. García-Ayllón, S. Rapid development as a factor of imbalance in urban growth of cities in Latin America: A perspective based on territorial indicators. Habitat. Int. 2016, 58, 127-142. [CrossRef]

38. World Bank. Urban Population (\% of the Total Population). 2020. Available online: https://data.worldbank. org/indicator/SP.URB.TOTL.IN.ZS (accessed on 1 January 2019).

39. Voudouris, K. Groundwater balance and safe yield of the coastal aquifer system in northeastern Korinthia, Greece. Appl. Geogr. 2006, 26, 291-311. [CrossRef]

40. UNWTO. UNWTO Tourism Highlights, 2016 Edition; UNWTO: Madrid, Spain, 2016. [CrossRef]

41. Canteiro, M.; Córdova-Tapia, F.; Brazeiro, A. Tourism impact assessment: A tool to evaluate the environmental impacts of touristic activities in Natural Protected Areas. Tour. Manag. Perspect. 2018, 220-227. [CrossRef]

42. Gómez, J.F. Acapulco: Despojo y turismo. Problemas del desarrollo. Rev. Latinoam. Econ. 1974, 5, 19.

43. Ponette-González, A.G.; Weathers, K.C.; Curran, L.M. Water inputs across a tropical montane landscape in Veracruz, Mexico: Synergistic effects of land cover, rain and fog seasonality, and interannual precipitation variability. Global Chang. Biol. 2010, 16, 946-963. [CrossRef]

44. INEGI. Censo de Población y Vivienda 1980-2015. 2019. Available online: https://www.inegi.org.mx/app/ tabulados/default.html?nc=mdemo02 (accessed on 7 March 2019).

45. WHO. World Health Organization, Programa Conjunto OMS/UNICEF de Monitoreo del Abastecimiento de Agua y del Saneamiento. Progress on Drinking Water, Sanitation and Hygiene: 2017 Update and SDG Baselines. OMS y UNICEF: Ginebra. 2017. Available online: http://www.who.int/mediacentre/news/releases/ 2017/launch-version-report-jmp-water-sanitation-hygiene.pdf (accessed on 7 March 2019). 
46. Jonathan, M.P.; Roy, P.D.; Thangadurai, N.; Srinivasalu, S.; Rodríguez-Espinosa, P.F.; Sarkar, S.K.; Lakshumanan, C.; Navarrete-López, M.; Muñoz-Sevilla, N.P. Metal concentrations in water and sediments from tourist beaches of Acapulco, Mexico. Marine Pollut. Bull. 2011, 62, 845-850. [CrossRef] [PubMed]

47. PMD. Plan Municipal de Desarrollo 2015-2018. 2015. Available online: http://www.acapulco.gob.mx/transparencia/ marco-normativo-y-juridico/plan-municipal-de-desarrollo-2015--2018/ (accessed on 7 October 2019).

48. INEGI. Usos de Suelo y Vegetación Series VI. 2017. Available online: https://www.inegi.org.mx/temas/ usosuelo/default.html\#Descargas (accessed on 7 March 2019).

49. WorldClim. World Clim Version 2. Feed the Future, The U. S. Government's Hunger \& Food Security Initiative. 2018. Available online: http://worldclim.org/version2 (accessed on 7 March 2019).

50. UAF. Alaska Satellite Facility. 2008. Available online: https://www.asf.alaska.edu/sar-data/palsar/terraincorrected-rtc/ (accessed on 7 March 2019).

51. CONANP. Comisión Nacional de Áreas Naturales Protegidas Información Espacial. 2018. Available online: http://sig.conanp.gob.mx/website/pagsig/info_shape.htm (accessed on 7 March 2019).

52. CONAGUA. Actualización de la Disponibilidad Media Anual de Agua en el Acuífero Bahía de Acapulco (1226) Estado de Guerrero. 2018. Available online: https://sigagis.conagua.gob.mx/gas1/Edos_Acuiferos_18/ guerrero/DR_1226.pdf (accessed on 5 September 2020).

53. CONAGUA. Actualización de la Disponibilidad Media Anual de Agua en el Acuífero La Sabana (1227) Estado de Guerrero. 2018. Available online: https://sigagis.conagua.gob.mx/gas1/Edos_Acuiferos_18/guerrero/DR_ 1227.pdf (accessed on 5 September 2020).

54. Carrascal, E.; Pérez, G.V. Ocupación territorial y deterioro ambiental ocasionado por la expansión urbano-turística en Acapulco, Guerrero. Investig. Geográficas 1998, 37. [CrossRef]

55. Kolb, M.; Mas, J.; Galicia, L. Evaluating drivers of land-use change and transition potential models in a complex landscape in Southern Mexico. Int. J. Geogr. 2013, 37-41. [CrossRef]

56. Liang, J.; Liu, Y.; Ying, L.; Li, P.; Xu, Y.; Shen, Z. Road impacts on spatial patterns of land-use and landscape fragmentation in three parallel rivers region, Yunnan Province, China. Chin. Geogr. Sci. 2014, 24, $15-27$. [CrossRef]

57. Yu, X.; Zhang, B.Q.; Li, Q.; Chen, J. A method characterizing urban expansion based on land cover map at $30 \mathrm{~m}$ resolution. Sci. China Earth Sci. 2016, 59, 1738-1744. [CrossRef]

58. Halmy, M.; Gessler, P.; Hicke, J.; Salem, B. Land use/land cover change detection and prediction in the north-western coastal desert of Egypt using Marcov-CA. Appl. Geogr. 2015, 63, 101-112. [CrossRef]

59. INEGI. Marco Geoestadístico Nacional. 2016. Available online: https://www.inegi.org.mx/temas/mg/default. html\#Descargas (accessed on 7 March 2017).

60. INEGI. Guerrero Carreteras, Escala 1:50,000. 2011. Available online: https://www.inegi.org.mx/temas/ viascomunicacion/default.html\#Descargas (accessed on 7 March 2019).

61. RNC. Red Nacional de Caminos 2015-2017. 2017. Available online: https://www.inegi.org.mx/temas/mapas/ viascomunicacion/ (accessed on 7 March 2019).

62. USGS. United States of Geological Survey, Science for a Changing World. 2019. Available online: https: //glovis.usgs.gov/ (accessed on 7 March 2019).

63. Chander, G.; Markham, B.L.; Helder, D.L. Summary of current radiometric calibration coefficients for Landsat MSS, TM, ETM+, and EO-1 ALI sensors. Remote Sens. Environ. 2009, 113, 893-903. [CrossRef]

64. Clark, M.L.; Aide, T.M.; Riner, G. Land change for all municipalities in Latin America and the Caribbean assessed from 250-m MODIS imagery (2001-2010). Remote Sens. Environ. 2012, 126, 84-103. [CrossRef]

65. Van Vliet, J.; Bregt, A.K.; Brown, D.G.; Van Delden, H. A review of current calibration and validation practices in land-change modeling environmental modelling \& software a review of current calibration and validation practices in land-change modeling. Environ. Model. Softw. 2016, 82, 174-182. [CrossRef]

66. Eastman, J.R. TerrSet Manual; Clark Labs, Clark University: Worcester, MA, USA, 2015.

67. Pan, S.; Tian, H.; Dangal, S.R.; Yang, Q.; Yang, J.; Lu, C.; Tao, B.; Ren, W.; Ouyang, Z. Responses of global terrestrial evapotranspiration to climate change and increasing atmospheric $\mathrm{CO}_{2}$ in the 21st century. Earth's Future 2015, 3, 15-35. [CrossRef]

68. Mondal, M.S.; Sharma, N.; Garg, P.K.; Kappas, M. Statistical independence test and validation of CA Markov land-use land cover (LULC) prediction results. Egypt. J. Remote Sens. Space Sci. 2016, 19, 259-272. [CrossRef]

69. INEGI. Ortofotos 1:10000 E14C47- E14C68, 1:20000 E14C47- E14C68; Files of Instituto Nacional de Estadística y Geografía offices: Acapulco, México, 2018. 
70. Google Earth. US Dept of State Geographer. E. U. 2018. Available online: https://www.google.es/intl/es/ earth/index.html (accessed on 7 March 2019).

71. Patil, M.B.; Desai, C.G.; Umrikar, B.N. Image classification tool for land-use /land cover analysis: A comparative study of maximum likelihood. Int. J. Geol. Earth Environ. Sci. 2012, 2, 189-196. Available online: https://www.cibtech.org/J-GEOLOGY-EARTH-ENVIRONMENT/PUBLICATIONS/2012/Vol_2_No_ 3/21-028...Bhavana...Image...Method.pdf (accessed on 7 March 2020).

72. Shaharum, N.S.N.; Shafri, H.Z.M.; Gambo, J.; Abidin, F.A.Z. Mapping of Krau Wildlife Reserve (KWR) protected area using Landsat 8 and supervised classification algorithms. Remote Sens. Appl. Soc. Environ. 2018, 10, 24-35. [CrossRef]

73. Cheng, J.; Huanga, Y.; Zhangd, H.; Wua, X. Characterization of elevation and land cover dependent trends of NDVI variations in the Hexi region, northwest China. J. Environ. Manag. 2019, 232, 1037-1048. [CrossRef]

74. Joorabian Shoosh, S.; Shayested, K.; Gholamalifard, M.; Azari, M.; Serrano-Notivoli, R.; López-Moreno, J.I. Impacts of future land cover and climate change on the water balance in northern Iran. Hydrol. Sci. J. 2017, 62, 2655-2673. [CrossRef]

75. Sangermano, F.; Eastman, J.R.; Zhu, H. Similarity weighted instance-based learning for the generation of transition potentials in land-use change modeling. Trans. GIS 2010, 14, 569-580. [CrossRef]

76. Takada, T.; Miyamoto, A.; Hasegawa, S.F. Derivation of a yearly transition probability matrix for land-use dynamics and its applications. Landsc. Ecol. 2010, 25, 561-572. [CrossRef]

77. Pontius, R.G.; Agrawal, A.; Huffaker, D. Estimating the uncertainty of land-cover extrapolations while constructing a raster map from tabular data. J. Geogr. Syst. 2003, 5, 253-273. [CrossRef]

78. Bergström, S. Development and Application of a Conceptual Runoff Model for Scandinavian Catchments; SMHI RHO, 7: Norrköping, Swedish, 1976; Volume 134.

79. Gao, H.; Tang, Q.; Shi, X.; Zhu, C.; Bohn, T.; Su, F.; Sheffield, J.; Pan, M.; Lettenmaier, D.; Wood, E.F. Water budget record from variable infiltration capacity (VIC) model. In Algorithm Theoretical Basis Document. Rapport_Version 1.2; Wood, E., Pan, M., Sheffield, J., Eds.; Lancaster University: Lancaster, UK, 2009; Volume 57, pp. 121-173.

80. Devi, G.K.; Ganasri, B.P.; Dwarakish, G.S. A review on hydrological models, international conference on water resources, coastal and ocean engineering (icwrcoe 2015). Aquat. Procedia 2015, 4, 1001-1007. [CrossRef]

81. Salvadore, E.; Bronders, J.; Batelaan, O. Hydrological modeling of urbanized catchments: A review and future directions. J. Hydrol. 2015, 529, 62-81. [CrossRef]

82. Minga-León, S.; Gómez-Albores, M.A.; Bâ, K.M.; Balcázar, L.; Manzano-Solís, L.R.; Cuervo-Robayo, A.P.; Mastachi-Loza, C.A. Estimation of water yield in the hydrographic basins of southern Ecuador. Hydrol. Earth Syst. Sci. Discuss 2018, 529. [CrossRef]

83. Redhead, J.W.; Stralford, C.; Sharps, K.; Jones, L.; Ziv, G.; Clarke, D.; Oliver, T.H.; Bullock, J.M. Empirical validation of the InVEST water yield ecosystem service model at a national scale. Sci. Total Environ. 2016, 569-570, 1418-1426. [CrossRef] [PubMed]

84. Fonseca, C.R.; Díaz-Delgado, C.; Esteller, M.V.; García-Pulido, D. Geoinformatics tool with an emergy accounting approach for evaluating the sustainability of water systems: A case study of the Lerma River, Mexico. Ecol. Eng. 2017, 99, 436-453. [CrossRef]

85. Thornton, P.E.; Thornton, M.M.; Mayer, B.W.; Wei, Y.; Devarakonda, R.; Vose, R.S.; Cook, R.B. Daymet: Daily Surface Weather Data on a 1-km Grid for North America, Version 3; ORNL DAAC: Oak Ridge, TN, USA, 2018. [CrossRef]

86. Thornthwaite, C.W.; Holzman, B. The determination of evaporation from land and water surfaces. Mon. Weather Rev. 1939, 67, 4-11. [CrossRef]

87. Dong, Q.; Zhan, C.; Wang, H.; Wang, F.; Zhu, M. A review on evapotranspiration data assimilation based on hydrological models. J. Geogr. Sci. 2016, 26, 230-242. [CrossRef]

88. Yates, D.; Strzepek, K. Potential Evapotranspiration Methods and Their Impact on the Assessment of River Basin Runoff under Climate Change; Working papers; IIASA: Luxemburg, 1994; p. 28. Available online: http://pure.iiasa.ac.at/id/eprint/4163/1/WP-94-046.pdf (accessed on 7 March 2020).

89. McKenney, M.S.; Rosenberg, N.J. The sensitivity of some potential evapotranspiration estimation methods to climate change. Agric. Forest Meteorol. 1993, 64, 81-110. [CrossRef] 
90. Pan, M.; Wood, E.F.; Wójcik, R.; McCabe, M.F. Estimation of the regional terrestrial water cycle using multi-sensor remote sensing observations and data assimilation. Remote Sens. Environ. 2008, 112, 1282-1294. [CrossRef]

91. Van der Schrier, G.; Jones, P.D.; Briffa, K.R. The sensitivity of the PDSI to the Thornthwaite and Penman-Monteith parametrizations for potential evapotranspiration. J. Geophys. Res. 2011, 116. [CrossRef]

92. Kanta, L.S.; Jha, M.K.; Chowdary, V.M. Assessing the accuracy of GIS-based multi-criteria decision analysis approaches for mapping groundwater potential. Ecol. Indic. 2018, 91, 24-37. [CrossRef]

93. Tesfaye, M.; Gessesse, G.; Kebede, A.; Chemeda, D. Effect of spatial scale on runoff coefficient: Evidence from the Ethiopian highlands. Int. Soil Water Conserv. Res. 2018, 6, 289-296. [CrossRef]

94. INEGI. Conjunto de Datos Vectoriales Perfiles de Suelos. 2013. Available online: https://www.inegi.org.mx/ temas/edafologia/default.html\#Descargas (accessed on 7 March 2019).

95. Liu, Y.B.; De Smedt, F. WetSpa Extension, a GIS-Based Hydrologic Model for Flood Prediction and Watershed Management; Vrije Universiteit Brussel: Brussel, Belgium, 2004; pp. 1-108.

96. Mahmoud, S.H.; Mohammad, F.S.; Alazba, A.A. Determination of potential runoff coefficient for Al-Baha Region, Saudi Arabia using GIS. Arab. J. Geosci. 2014, 7, 2041-2057. [CrossRef]

97. Ribolzi Patin, J.; Bresson, L.M.; Latsachack, K.O.; Mouche, E.; Sengtaheuanghoung, O.; Silvera, N.; Thiébaux, J.; Valentin, C. Impact of slope gradient on soil surface features and infiltration on steep slopes in northern Laos. Geomorphology 2011, 127, 53-63. [CrossRef]

98. Mu, W.; Yu, F.; Li, C.; Xie, Y.; Tian, J.; Liu, J.; Zhao, N. Effects of rainfall intensity and slope gradient on runoff and soil moisture content on different growing stages of spring maize. Water 2015, 7, 2990-3008. [CrossRef]

99. Birhanu, A.; Masih, I.; van der Zaag, P.; Nyseen, J.; Cai, X. Impacts of land use and land cover changes on the hydrology of the Gumara catchment, Ethiopia. Phys. Chem. Earth 2019, 112, 165-174. [CrossRef]

100. Nash, J.E.; Sutcliffe, J.V. River flow forecasting through conceptual models. Part 1- A discussion of principles. J. Hydrol. 1970, 10, 282-290. [CrossRef]

101. CONAGUA. Banco Nacional de Datos de Aguas Superficiales. 2019. Available online: http://www.conagua. gob.mx/CONAGUA07/Contenido/Documentos/Portada\%20BANDAS.htm (accessed on 7 March 2019).

102. Smakhtin, V.U. Estimating continuous monthly baseflow time series and their possible applications in the context of the ecological reserve. Water SA 2001, 27, 213-217. [CrossRef]

103. Veldkamp, T.I.E.; Zhao, F.; Ward, P.J.; de Moel, H.; Aerts, J.C.; Müller Schmied, H.; Portmann, F.T.; Masaki, Y.; Pokhrel, Y.; Liu, X. Human impact parameterizations in global hydrological models improve estimates of monthly discharges and hydrological extremes: A multi-model validation study. Environ. Res. Lett. 2018, 13, 55008. [CrossRef]

104. Giorgetta, M.A.; Jungclaus, J.; Reick, C.H. Climate and carbon cycle changes from 1850 to 2100 in MPI-ESM. J. Adv. Modeling Earth Syst. 2013, 5, 572-597. [CrossRef]

105. Paredes-Tavares, J.; Gómez-Albores, M.A.; Mastachi-Loza, C.A.; Díaz-Delgado, C.; Becerril-Piña, R.; Martínez-Valdés, H.; Bâ, K.M. Impacts of climate change on the irrigation districts of the Rio Bravo Basin. Water 2018, 10, 258. [CrossRef]

106. Richards, J.A.; Jia, X. Interpretation of hyperspectral image data. Remote Sens. Digit. Image Anal. 1999, 313-337. [CrossRef]

107. Moeck, C.; Grech-Cumbo, N.; Podgorski, J.; Bretzler, A.; Gurdak, J.J.; Berg, M.; Schimer, M. A global-scale dataset of direct natural groundwater recharge rates: A review of variables, processes and relationships. Sci. Total Environ. 2020, 717, 137042. [CrossRef] [PubMed]

108. Nakicenovic, N.; Alcamo, J.; Davis, G.; de Vires, B.; Fenhann, J.; Graffin, S.; Gregory, K.; Grübler, A.; Yong, T.; Kram, T.; et al. Special Report on Emissions Scenarios, Intergovernmental Panel on Climate Change; Cambridge University Press: Cambridge, UK, 2000; p. 599. Available online: https://www.ipcc.ch/site/assets/uploads/ 2018/03/emissions_scenarios-1.pdf (accessed on 7 March 2020).

109. Perevochtchikova, M.; Rojo, I.A.; Teyeliz, E.; Martínez, J.; Saavedra, D. Integrated Evaluation of the Effects of the Payment for Hydrological Environmental Services Program in Ajusco, Mexico City; Springer: Cham, Switzerland, 2019; pp. 283-303.

110. Musakwa, W.; Tshesane, R.M.; Kangethe, M. The strategically located land index support system for human settlements land reform in South Africa. Cities 2017, 60, 91-101. [CrossRef] 
111. Tiwari, A.; Tyagi, D.; Sharma, S.K.; Suresh, M.; Jain, K. Multi-Criteria Decision Analysis for Identifying Potential Sites for Future Urban Development in Haridwar, India; ICCCE 2018; Kumar, A., Mozar, S., Eds.; Springer: Singapore, 2019; pp. 760-776.

112. Salata, S.; Giaimo, C.; Barbieri, C.A.; Garnero, G. The utilization of ecosystem services mapping in land use planning: The experience of LIFE SAM4CP Project. J. Environ. Plan. Manag. 2020, 63, 523-545. [CrossRef]

113. Cominoa, E.; Botterob, M.; Pomarico, S.; Rosso, M. Exploring the environmental value of ecosystem services for a river basin through spatial multicriteria analysis. Land Use Policy 2014, 36, 381-395. [CrossRef]

(C) 2020 by the authors. Licensee MDPI, Basel, Switzerland. This article is an open access article distributed under the terms and conditions of the Creative Commons Attribution (CC BY) license (http://creativecommons.org/licenses/by/4.0/). 